\title{
NO1, a New Sigma 2 Receptor/TMEM97 Fluorescent Ligand, Downregulates SOCE and Promotes Apoptosis in the Triple Negative Breast Cancer Cell Lines
}

\author{
Carlos Cantonero ${ }^{1}$, Pedro Javier Camello ${ }^{1} \mathbb{(}$, Carmen Abate $^{2}\left(\mathbb{D}\right.$, Francesco Berardi $^{2}$, \\ Gines Maria Salido ${ }^{3}$, Juan Antonio Rosado ${ }^{3,+}\left(\mathbb{D}\right.$ and Pedro C. Redondo ${ }^{3, *,+} \mathbb{D}$ \\ 1 Department of Physiology, Phycell and FIMUL Groups, University of Extremadura, 10003 Caceres, Spain; \\ carloscantonerovet@gmail.com (C.C.); pcamello@unex.es (P.J.C.) \\ 2 Dipartimento di Farmacia-Scienze del Farmaco, Università degli Studi di Bari "Aldo Moro", Via Orabona 4, \\ I-70125 Bari, Italy; carmen.abate@uniba.it (C.A.); francesco.berardi@uniba.it (F.B.) \\ 3 Institute of Molecular Pathology Biomarkers (IMPB) of University of Extremadura, 10003 Caceres, Spain; \\ gsalido@unex.es (G.M.S.); jarosado@unex.es (J.A.R.) \\ * Correspondence: pcr@unex.es; Tel.: +34-92-725-7106 (ext. 51522); Fax: +34-92-725-7110 \\ + Both authors share the same level of authorship and responsibility in the present work.
}

Received: 4 December 2019; Accepted: 16 January 2020; Published: 21 January 2020

\begin{abstract}
Background: The structure of the Sigma 2 receptor/TMEM97 (б2RTMEM97) has recently been reported. $(2,3)$ Methods and results: We used genetic and biochemical approaches to identify the molecular mechanism downstream of $\sigma 2 \mathrm{R} / \mathrm{TMEM} 97$. The novel $\sigma 2 \mathrm{R} / \mathrm{TMEM} 97$ fluorescent ligand, NO1, reduced the proliferation and survival of the triple negative breast cancer cell lines (TNBC: MDA-MB-231 and MDA-MB-468 cell lines), due to NO1-induced apoptosis. Greater bioaccumulation and faster uptake of NO1 in MDA-MB-231 cells compared to MCF10A or MCF7 cell lines were also shown. Accordingly, elevated $\sigma 2 \mathrm{R} / \mathrm{TMEM} 97$ expression was confirmed by Western blotting. In contrast to NO1, other o2R/TMEM97 ligands, such as SM21 and PB28, enhanced MDA-MB-231 cell proliferation and migration. Store-operated calcium entry (SOCE) is crucial for different cancer hallmarks. Here, we show that NO1, but not other o2R/TMEM97 ligands, reduced SOCE in MDA-MB-231 cells. Similarly, TMEM97 silencing in MDA-MB-231 cells also impaired SOCE. NO1 administration downregulated STIM1-Orai1 interaction, probably by impairing the positive regulatory effect of $\sigma 2 \mathrm{R} / \mathrm{TMEM} 97$ on STIM1, as we were unable to detect interaction with Orai1. (4) Conclusion: б2R/TMEM97 is a key protein for the survival of triple negative breast cancer cells by promoting SOCE; therefore, NO1 may become a good pharmacological tool to avoid their proliferation.
\end{abstract}

Keywords: б2R/TMEM97; STIM1; SOCE; NO1; MDA-MB-231 cells

\section{Introduction}

Cancer cell proliferation results from a dysregulated cell cycle and an impaired cell-death signaling mechanism, where changes in the cytosolic free- $\mathrm{Ca}^{2+}$ concentration play a relevant role. Store operated $\mathrm{Ca}^{2+}$ entry (SOCE) is considered as a major $\mathrm{Ca}^{2+}$-entry mechanism in nonelectrically excited cells; it is regulated by emptying of the intracellular $\mathrm{Ca}^{2+}$ stores, such as the endoplasmic reticulum (ER). Enhanced SOCE has been reported in different cancer types, including human colorectal cancer, osteosarcoma, and ovary carcinoma [1,2]. In addition, SOCE remodeling, due to changes in the expression of its key molecular components, has been also evidenced in several types of cancer, such as colorectal cancer and oral/oropharyngeal squamous cell carcinoma [3]. In different breast cancer cell 
lines, including the estrogen receptor positive, MCF7, or the triple negative breast cancer cell line (TNBC), MDA-MB-231 cells, SOCE has been reported to be enhanced as compared to nontumoral cell lines [4,5]. In MCF7 cells, SOCE depends on STIM1, STIM2, and Orai3, whereas in MDA-MB-231 cells, STIM1 activates $\mathrm{Ca}^{2+}$ entry through Orai1 [4,6]. Previous reports in MDA-MB-231 cells showed an enhanced expression of Orai1 [4]. Furthermore, STIM1 expression silencing attenuated the ability of MDA-MB-231 cells to proliferate and migrate in vivo [7]. In agreement with this, Orai1 silencing in MDA-MB-231 cells impaired proliferation and metastasis [8,9]. Finally, a recent study using a new synthetic antagonist of Orai1 (triazole derivative compound) demonstrated a functional role of this channel in MDA-MB-231 cell proliferation, subsequently reinforcing the relevance of SOCE in cancer progression [10]. It is worth noting that STIM1 was found to be overexpressed in samples from breast cancer patients $[7,11]$.

Sigma receptor $(\sigma R)$ family members were initially described as potent neuronal opioid receptors. The administration of their specific agonists was shown to be particularly efficient in the treatment of neuroleptic patients, and useful in the therapy of the schizophrenia [12-14]. The existence of two members within this family, $\sigma 1 R$ and $\sigma 2 R$, was discovered on the basis of their different pharmacological profiles. Recently, $\sigma 2 \mathrm{R}$ was identified as TMEM97, which is, at present, described as a cholesterol transport regulator [15], but controversy regarding its structure and identity remains [16]. Thus, chemical synthesis of novel $\sigma 2 R / T M E M 97$ ligands will be an emerging scientific field, since this protein was reported to be highly expressed in several cancer cell types. Interestingly, the current evidence indicates that the use of different agonists of $\sigma$ Rs downregulates cell proliferation $[17,18]$. In fact, it has been proposed that agonists of both $\sigma 1 \mathrm{R}$ and $\sigma 2 \mathrm{R} / \mathrm{TMEM} 97$ are efficient antitumor drugs $[19,20]$. Regarding the role of $\sigma R /$ TMEM97 in breast cancer, it has been recently described that the protein family involved in DNA damage, Poly (ADP-ribose) polymerase, and $\sigma \mathrm{R} / \mathrm{TMEM} 97 \mathrm{might}$ share the same signaling pathway in order to impair breast cancer cell proliferation [21]. Furthermore, the development of new labelling probes for $\sigma 2 \mathrm{R} / \mathrm{TMEM} 97$ is an emerging hot-topic due to their relevance as diagnostic imaging tools for detecting breast solid tumors [22].

A role for $\sigma 2 \mathrm{R} / \mathrm{TMEM} 97$ in the intracellular $\mathrm{Ca}^{2+}$ homeostasis has been suggested, but it has yet to be investigated $[23,24]$. Firstly, it was reported that incubation of human neuroblastoma SK-N-SH cells with the $\sigma 2 R$ ligands like CB-64D, CB-64L, JL-II-147, BD737, LR172, BD1008, haloperidol, reduced-haloperidol, and ibogaine evoked a rise in cytosolic $\mathrm{Ca}^{2+}$ concentration in the absence and presence of extracellular $\mathrm{Ca}^{2+}$. $\mathrm{Ca}^{2+}$ mobilization by activation of $\sigma 2 \mathrm{R}$ was mediated by empting both thapsigargin (TG)-sensitive and -insensitive reservoirs [23]. The $\sigma 2 R$ agonist, F281, was able to mobilize $\mathrm{Ca}^{2+}$ from the ER and mitochondria in SK-N-SH cells [24]. Furthermore, it was reported that $\sigma 2 \mathrm{R} / \mathrm{TMEM} 97$ may be a negative regulator of voltage-activated $\mathrm{Ca}^{2+}$ channel in neurons [25]. On the other hand, the role of $\sigma 2 \mathrm{R} / \mathrm{TMEM} 97$ on $\mathrm{Ca}^{2+}$ homeostasis in triple negative breast cancer cells remains largely unexplored. Here, we aim to elucidate the regulation of SOCE by NO1, a novel $\sigma 2 \mathrm{R} / \mathrm{TMEM} 97$ ligand, in the triple negative breast cancer cell line, MDA-MB-231. Our results indicate that NO1 downregulates SOCE probably by impairing the interaction of $62 \mathrm{R} / \mathrm{TMEM} 97$ with STIM1, which may be required for its interaction with Orai1. The incubation of MDA-MB-231 cells with NO1 results in the attenuation of cell proliferation and migration, due to the induction of apoptosis via caspase- 9 activation that was also observed in these cells.

\section{Results}

\section{1. $\sigma 2 R / T M E M 97$ Is Overexpressed in Breast Cancer Cell Lines}

The overexpression of $\sigma 2 R / T M E M 97$ has previously been reported in certain cells isolated from different cancer types [26]. As the structure of this protein has long been controversial [27-29], we firstly analyzed the expression of $\sigma 2 \mathrm{R} / \mathrm{TMEM} 97$ by WB using a specific anti-TMEM97 antibody (see Figure 1a, $n=6$ ), which has been reported to enhance protein expression in MDA-MB-231 cells, as compared to the MCF10A and MCF7 cell lines. Additionally, we took advantage of the fluorescent property 
of NO1, a novel $62 \mathrm{R} / \mathrm{TMEM} 97$ ligand (NO1: (2-\{6-[2-(3-(6,7-dimethoxy-3,4-dihydroisoquinolin-2 (1H)-yl)propyl)-3,4-dihydroisoquinolin-1(2H)-one-5-yloxy]hexyl\}-5-(dimethylamino)isoindoline-1,3dione), which was recently designed as a $\sigma 2 \mathrm{R}$ specific fluorescent ligand $\left(K_{\mathrm{i}}: 10.2 \pm 2.4 \mathrm{nM}\right.$; while its $K_{\mathrm{i}}$ for $\sigma 1 \mathrm{R}$ is over $5000 \mathrm{nM}$ ) [30]. Thus, MCF10A, MCF7, and MDA-MB-231 cells were incubated at room temperature with $\mathrm{NO} 1(100 \mathrm{nM})$ for $5 \mathrm{~min}$. Then, the cells were observed under confocal microscopy (Figure 1b, n=4). As depicted in Figure 1b, we confirmed the enhanced NO1 fluorescence bioaccumulation derived from the elevated presence of $\sigma 2 \mathrm{R} / \mathrm{TMEM} 97$ in MDA-MB-231 cells as compared to MCF10A cells. Next, NO1 cell uptake was analyzed using a spectrofluorophotometer, which revealed an increase in NO1 fluorescence of $46.6 \pm 10.4 \%$ in MDA-MB-231 cells respect to MCF10A cells (Figure 1c, $n=5 ; p<0.01)$. In addition, both cell lines were exposed to NO1 (100 nM) at room temperature, and we monitored the dye uptake capability of the different cell types for $30 \mathrm{~min}$ with an epifluorescent microscope. As evidenced by comparing the results shown in the Video S1 and Video S2, we observed that NO1 was more quickly incorporated and redistributed into the cytosol of the MDA-MB-231 cells. This observation confirms the images obtained by confocal microscopy, in which we incubated the cells with NO1 for shorter time-periods. In fact, NO1 incorporation in MCF10A became evident after a longer exposition period (around $20 \mathrm{~min}$ ). In contrast to MDA-MB-231 cells, MCF10A cells did not redistribute the dye into the different intracellular locations or organelles, and therefore, NO1 remained largely accumulated near the plasma membrane (see Video S1 vs. Video S2). Therefore, these results showing enhanced $\sigma 2 \mathrm{R} / \mathrm{TMEM} 97$ expression in cancer cells agree with previous findings obtained using different experimental approaches [26,31].

\section{2. $\sigma 2 R / T M E M 97$ Ligands Alter TNBC Cell Proliferation and Migration}

As observed in the supplementary videoclips, NO1 significantly altered the morphology of the MDA-MB-231 cells as compared to MCF10A that remained almost unaltered (Video S1 \& Video S2). Hence, we examined whether $\sigma 2 \mathrm{R} / \mathrm{TMEM} 97$ was required for MDA-MB-231 cell function. This issue was investigated by monitoring the BrdU accumulation in cells using an TECAN M200 Infinite pro ELISA plate reader (Tecan Trading Ltd, Mannedorf, Switzerland) plate reader device and o2R/TMEM97 ligands, such as NO1, SM21, and PB28. As shown in Figure 2a, MDA-MB-231 cells cultured for $48 \mathrm{~h}$ in the presence of the SM21 (100 nM), which was previously described as a $\sigma 2 R / T M E M 97$ antagonist, showed an increase of $265.0 \pm 14.0 \%$ in BrdU staining, as compared to the values observed at the beginning of the experiments (time $0 \mathrm{~h}$ ). Interestingly, cell cultures under control conditions exhibited an increase in BrdU staining of $140.0 \pm 14.0 \%$ with respect the value found at time 0 (Figure 2a, black trace); thus, SM21 enhanced MDA-MB-231 cell proliferation. Additionally, we incubated the cells with PB28, a previously described $\sigma 2 R / T M E M 97$ agonist that may also act as $\sigma 1 R$ antagonist. In fact, according to the literature, PB28 acts as a $62 \mathrm{R} / \mathrm{TMEM} 97$ ligand and evokes cell death in several cancer cell lines such as pancreatic cancer cells $[18,32,33]$. 


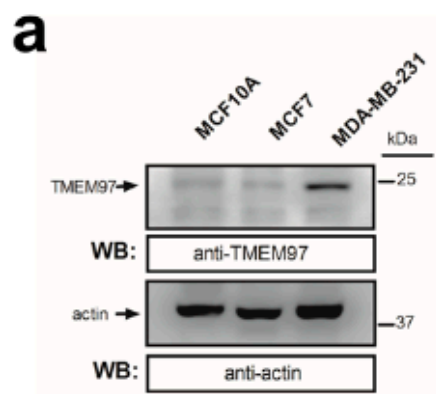

b

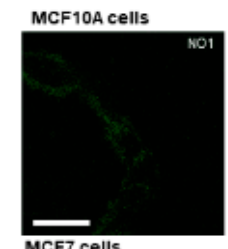

MCF7 cells

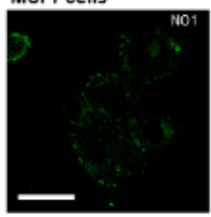

MDA-MB-231 cells

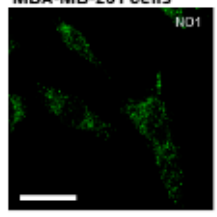

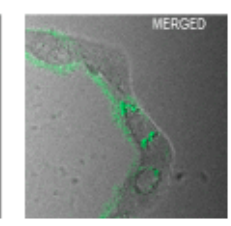
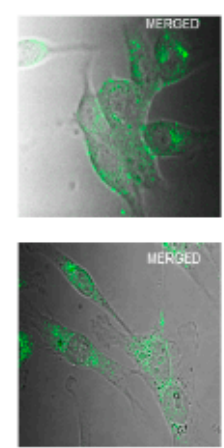

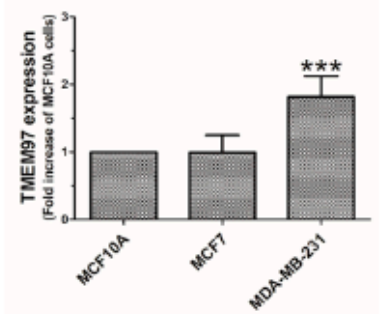

C

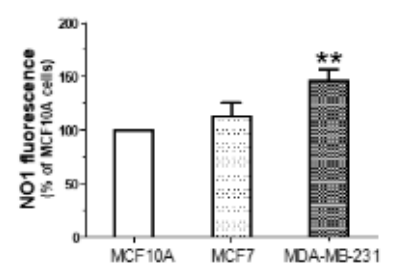

Figure 1. $\sigma 2 \mathrm{R} / \mathrm{TMEM} 97$ expression in MCF10A, MCF7, and MDA-MB-231 cell lines. MCF10A, MCF7 and MDA-MB-231 cells were shed onto coverslips at the same concentration $\left(1 \times 10^{6} \mathrm{cells} / \mathrm{mL}\right)$. (a) Cells were detached and lysed with Laemmli's buffer for subsequent WB using a specific anti-TMEM97 antibody as described in the Material and Methods section. Bar graph represents the fold increase of $\sigma 2 \mathrm{R} / \mathrm{TMEM} 97$ expression relative to MCF10A normalized with the actin content that was used as loading control. (b) Alternatively, coverslips were incubated for $5 \mathrm{~min}$ with $100 \mathrm{nM}$ of NO1 at room temperature and were mounted under a confocal fluorescent microscope, where samples were excited at $390 \mathrm{~nm}$. The resulting NO1 fluorescence was acquired at a wavelength of $505 \mathrm{~nm}$. Images were focused in the middle-cell plane, using a $40 \times$-immersion oil objective, and are representative of three independent experiments. Bar represents $30 \mu \mathrm{m}$. (c) Cells treated with NO1, as described above, were detached, washed, and resuspended in $1 \mathrm{~mL}$ of PBS inside a quartz cuvette. NO1 fluorescence emitted by the samples was recorded using a spectrofluorophotometer (Ex/Em: $390 \mathrm{~nm} / 505 \mathrm{~nm})$. Bar graph represents the percentage of NO1 fluorescence compared to the values found in MCF10A, presented as the mean \pm S.E.M. of five independent experiments. ${ }^{* *},{ }^{* * *}$ : represent $p<0.01$ and $<0.001$ as compared to MCF10A. 
a

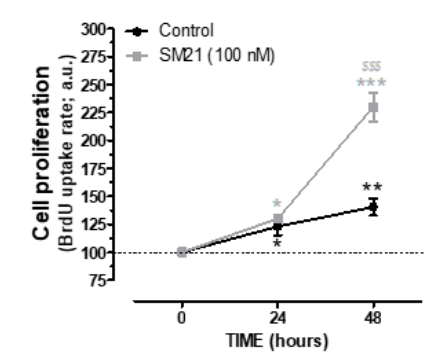

\section{MDA-MB-231}

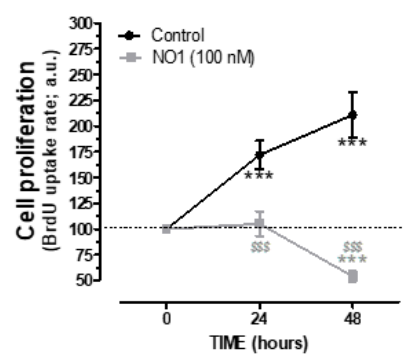

\section{b MDA-MB-231}

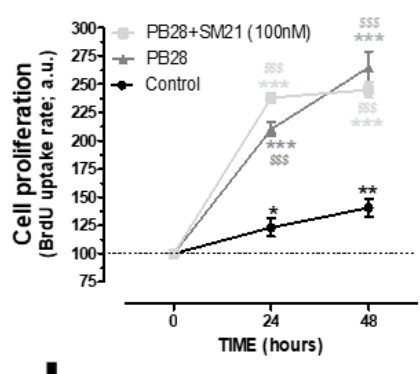

d

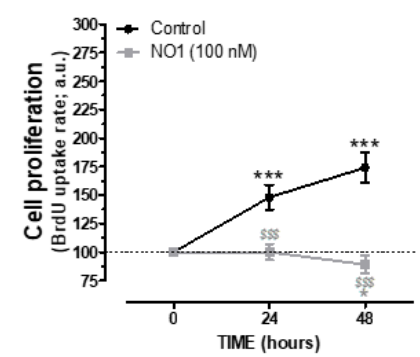

e

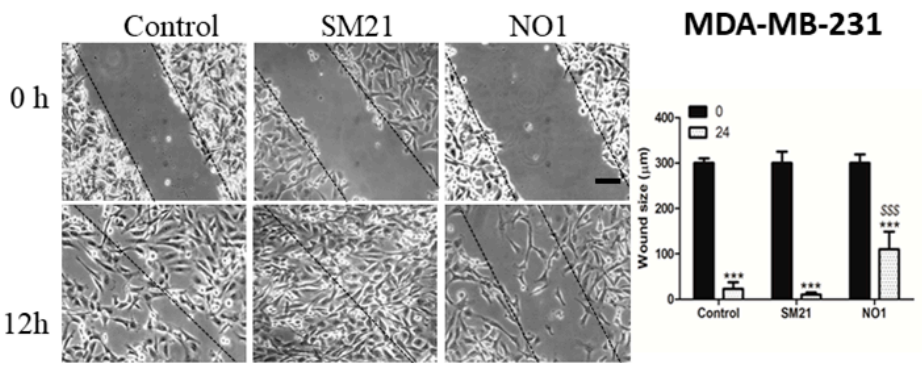

Figure 2. $\sigma 2 \mathrm{R} / \mathrm{TMEM} 97$ is involved in the proliferation and migration of triple negative breast cancer cell lines (TNBC) cells. (a) MDA-MB-231 cells were shed onto coverslips $\left(0.5 \times 10^{6}\right.$ cells $\left./ \mathrm{mL}\right)$, and at day 0 , the cell culture was supplemented with either the vehicle control, (a-d), SM21, $100 \mathrm{nM},(\mathbf{a}, \mathbf{b})$, PB28 (1 nM, dark-grey trace, (b), dark grey trace) and a combination of PB28 + SM21 ((b), light-grey trace). Cells were cultured for at least $48 \mathrm{~h}$ under normal growing condition $\left(37^{\circ} \mathrm{C}\right.$ and $5 \% \mathrm{CO}_{2}$ in the incubator). Alternatively, TBNC cell lines, MDA-MB-231 (c) and MDA-MB-468 cells (d) were grown for $48 \mathrm{~h}$ in the absence or presence of $100 \mathrm{nM}$ of NO1. At the time points indicated, cells were allowed to incorporate the BrdU during $2 \mathrm{~h}$, and were then processed following the protocol recommended by the manufacture's company. BrdU incorporation was analyzed by determining the absorbance at $450 \mathrm{~nm}$ using a TECAN ELISA plate reader. Graphs are representative of six independent experiments. (e) MDA-MB-231 cells were shed and cultured for $24 \mathrm{~h}$, thus allowing cells to reach the adequate confluence; next, cells were incubated for 5 min with NO1 $(100 \mathrm{nM})$, and further, cells were also cultured in parallel in the presence of either the vehicle (control) or SM21 (100 nM) throughout the entire experiment. At the beginning of the experiments, a scratch was done in the cell culture (time 0 ), and in the following hours, we took images of the cell culture using a light-field-microscope and a 10x objective. Experiments lasted until a complete closure of the scratch in the control cell cultures was observed, which occurred after around $12 \mathrm{~h}$ in most cases. The dotted lines define the areas lacking cells. Bar represents $100 \mu \mathrm{m} .{ }^{*}, * *$, and ${ }^{* * *}$ represent $p<0.05,<0.01$, and $p<0.001$, respectively, compared to the BrdU values found at time $0 . \$ \$ \$: p<0.001$ compared to the cells nontreated with the $\sigma 2 \mathrm{R} / \mathrm{TMEM} 97$ ligands at any given time point. 
Incubation of MDA-MB-231 cells for $48 \mathrm{~h}$ with PB28 (1 nM) significantly increased cell growth. PB28 treatment enhanced cell growth more than SM21 (see dark-grey traces in Figure 2a,b). Cell treatment with a combination of both ligands (SM21 + PB28) resulted in a quick increase in cell growth at $24 \mathrm{~h}$; however, thereafter, a slight but not significant decrease in the cell count was found at $48 \mathrm{~h}$. These results led us to conclude that interference of the $\sigma 2 R / T M E M 97$ activity modifies the MDA-MB-231 cell proliferation. Finally, to determine the efficiency of NO1 as a possible antiproliferative drug in TNBC cells lines, both MDA-MB-231 and MDA-MB-468 cells were grown as previously described in the absence or presence of NO1 $(100 \mathrm{nM})$. Our results indicate that treatment with NO1 resulted in a significant decrease in cell proliferation of both cell lines (Figure 2c,d). MDA-MB-468 cells have substantial differences as compared to MDA-MB-231 cells, since the former were derived from a noncaucasic patient, representing a much more aggressive type of breast tumor. Finally, the characteristic alteration of the RAS family of genes described in the MDA-MB-231 cells has not been reported for MDA-MB-468 cells [34].

Next, we evaluated the possible role of $\sigma 2 R / T M E M 97$ in the ability of MDA-MB-231 cells to migrate. Migration was assessed using the wound-healing assay as described elsewhere [2]. This protocol revealed that SM21 $(100 \mathrm{nM})$ evoked a rapid close up of the scratch at $12 \mathrm{~h}$; meanwhile, small gaps between cells could still be observed under control conditions at that time point (Figure 2e; middle panels versus left hand side panels and the beside bar graph). By contrast, incubation of MDA-MB-231 cells with NO1 (100 nM) for 5 min before the scratch was enough to significantly inhibit the MDA-MB-231 cell migration, as evidenced by the wide gap observed after $12 \mathrm{~h}$ of scratch (Figure 2e; left hand side panel vs. right hand side panel and the beside bar graph). This demonstrates that the $\sigma 2 \mathrm{R} / \mathrm{TMEM} 97$ ligand, NO1, reduced cell migration; meanwhile, SM21 has the opposite effect in migration. Altogether, these results reveal a relevant functional role $\sigma 2 \mathrm{R} / \mathrm{TMEM} 97$ on triple negative MDA-MB-231 breast cancer cells which agrees with previous results obtained in other cell models, as well as with different $\sigma 2 \mathrm{R} / \mathrm{TMEM} 97$ agonists $[35,36]$.

\subsection{NO1 Promotes Cell Death and Apoptosis in MDA-MB-231 Cells}

Previous studies have reported antitumoral effects of $\sigma 2 R /$ TMEM97 ligands [21,37,38]. In our experiments, incubation of MDA-MB-231 cells with NO1 for 30 min caused membrane blebbing and cell morphology disruption that were less evident in MCF10A (see Video S1 and Video S2), but also a reduction in the MDA-MB-231 cell proliferation and migration capabilities (Figure 2). Therefore, we speculate about the possible antitumoral action of NO1. Firstly, we evaluated the propidium iodide (PI) staining of MCF10A cells, MCF10A cells artificially overexpressing TMEM97, and MDA-MB-231 cells. Therefore, cells were cultured on coverslips for $48 \mathrm{~h}$ to facilitate cell growth, attachment, and artificial expression of TMEM97, which was evidenced by the positive fluorescence derived from its YFP-tag. Next, we replaced the culture medium with Hepes buffer saline (HBS) supplemented with propidium iodide (PI, $4 \mu \mathrm{M}$ ). Then, cells were placed for $45 \mathrm{~min}$ at $37^{\circ} \mathrm{C}$ inside the incubator, and NO1 (100 nM) or the vehicle were added to the extracellular medium for the last $30 \mathrm{~min}$ of incubation. As shown in Figure 3a,b, treatment with NO1 enhanced PI staining. An increase in the number of cells positively stained with PI, i.e., 5 times more cells, were found in NO1-treated MDA-MB-231 cells compared to the untreated cells (white bar in Figure 3a). In addition, NO1 administration to MCF10A resulted in enhanced PI loading, but the increase in PI staining was lower than that in NO1-treated MDA-MB-231 cells (See Figure 3b,c and histogram in Figure 3a).

Interestingly, the percentage of MCF10A positively stained with PI upon NO1 administration increased very significantly upon overexpression of TMEM97 (Figure 3a,c). An analysis of the fluorescence images emitted by NO1 and YFP-TMEM97 overexpressed in MCF10A revealed a relatively high degree of colocalization (Figure S1). These data indicate that NO1 may be evoking cell death by interacting with $\sigma 2 R / T M E M 97$; this would explain the aforementioned reduction in the migration capability of MDA-MB-231 cells. In order to extend our knowledge regarding the mechanism underlying the effect of NO1 on MDA-MB-231 cells, we investigated the possible proapoptotic effect of 
NO1 on MDA-MB-231 cells by flow-cytometry and using the BrdU-based TUNEL technique described in the Material and Methods section.

a

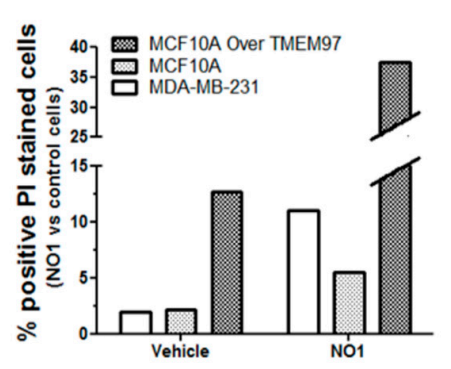

C

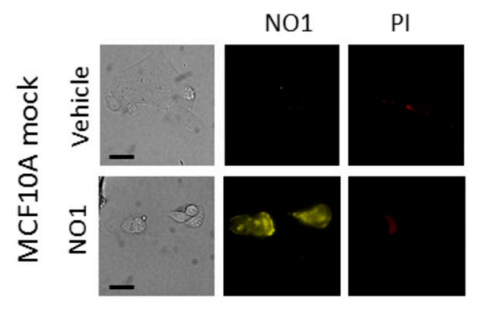

b
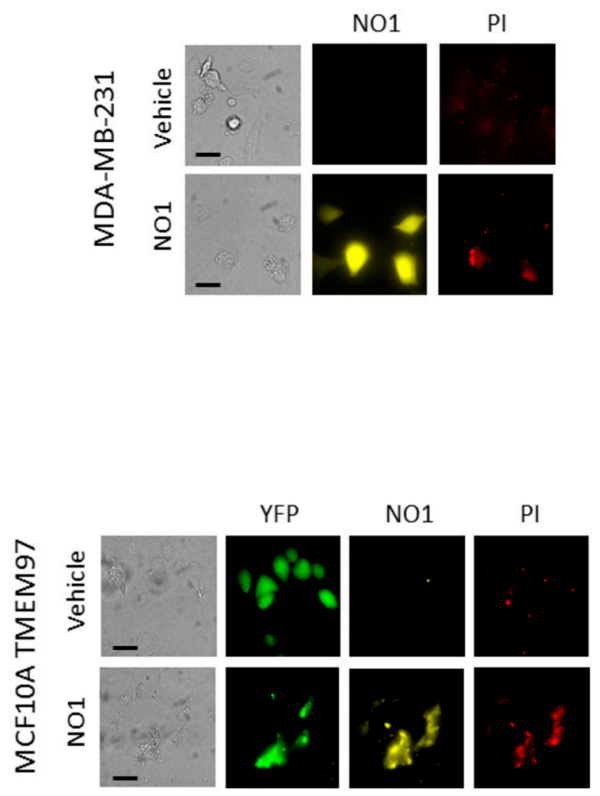

Figure 3. NO1 cell death as evidenced by the PI staining in MDA-MB-231 cells. (a-c) MDA-MB-231 cells, MCF10A, and MCF10A overexpressing TMEM97 cells were shed at the appropriate concentration, and were incubated for $45 \mathrm{~min}$ with propidium iodide (PI, $4 \mu \mathrm{M}$ ). During the final $30 \mathrm{~min}$, the extracellular medium was supplemented with either the vehicle or NO1 (100 nM). When the incubation time was over, pictures of the different cells under the different experimental conditions were acquired, as described in the Material and Methods section. (a) Bar graph represents the percentage of positive PI stained cells after administration of NO1 vs. nontreated cells (vehicle), which results of the analysis of around 200 cells from four different independent transfections. Bars in the images represent $50 \mu \mathrm{m}$.

As depicted in Figure 4a, the incubation of MDA-MB-231 cells for 5 min with NO1 (100 nM) evoked a significant increase of $24.0 \pm 8.0 \%(p<0.01 ; n=4)$ in the number of apoptotic cells as compared to untreated cells.

In order to rule out possible NO1 off targets which were different from o2R/TMEM97, we analyzed the effect of NO1 on MCF10A cells (Figure 4b), which presented a low level of $\sigma 2 R / T M E M 97$ expression, as previously evidenced in Figure 1. As expected, NO1 (100 nM) administration for $5 \mathrm{~min}$ to MCF10A cells did not evoke the activation of apoptosis $(2.0 \pm 5.0 \% ; p>0.05 ; n=6)$. Interestingly, cisplatin treatment did not alter the percentage of apoptotic cells $(2.0 \pm 3.0 \% ; p>0.05 ; n=6)$, and only the combination of both drugs was able to evoke an increase in the percentage of the MCF10A apoptotic cells, but it lacks of statistical significance $(2.0 \pm 3.0 \% ; p>0.05 ; n=6)$. Overall, the percentage of apoptotic cells observed in the experiments using MCF10A were less significant than those observed in MDA-MB-231 cells (compare histograms of Figure 4a,b).

Next, we analyzed the downstream cell death mechanisms induced by the incubation of MDA-MB-231 cells with NO1. Thus, MDA-MB-231 cell samples were incubated for 5 min with $100 \mathrm{nM}$ of NO1, or were kept under resting conditions. Subsequently, all the samples were solved by Western blotting using the anticaspase 9, anti-GRP78 and antiphospho-eiF2 $\alpha$ antibodies in order to ascertain whether NO1 might activate either mitochondrial-dependent $[38,39]$ or ER stress-dependent apoptotic pathways $[40,41]$, respectively. Additionally, membranes were probed with anti-LC3 antibody to ascertain the LC3I/LC3I ratio that is indicative of the possible activation of autophagy in response to NO1 [42]. 62R/TMEM97 was not localized in the mitochondria, as reflected by the lack of NO1 colocalization with mitotracker both in resting 
and in TG-activated cells (see confocal images in the Figure S2a,b, respectively). However, NO1 interfered with $02 \mathrm{R} / \mathrm{TMEM} 97$ activity, and subsequently, evoked the activation of a mitochondrial-dependent apoptotic pathway. This fact was evidenced by the increase of $16.0 \pm 8.0 \%$ observed in the content of active caspase $9(35 \mathrm{kDa})$, which was in parallel with the decrease in the content of the inactive procaspase $9(47 \mathrm{kDa})$ (Figure $5 \mathrm{a} ; p<0.05 ; \mathrm{n}=3)$. In contrast, NO1 did not activate the other cell death pathways analyzed here, such as ER stress or autophagy (Figure $5 \mathrm{~b}, \mathrm{c}$ ).
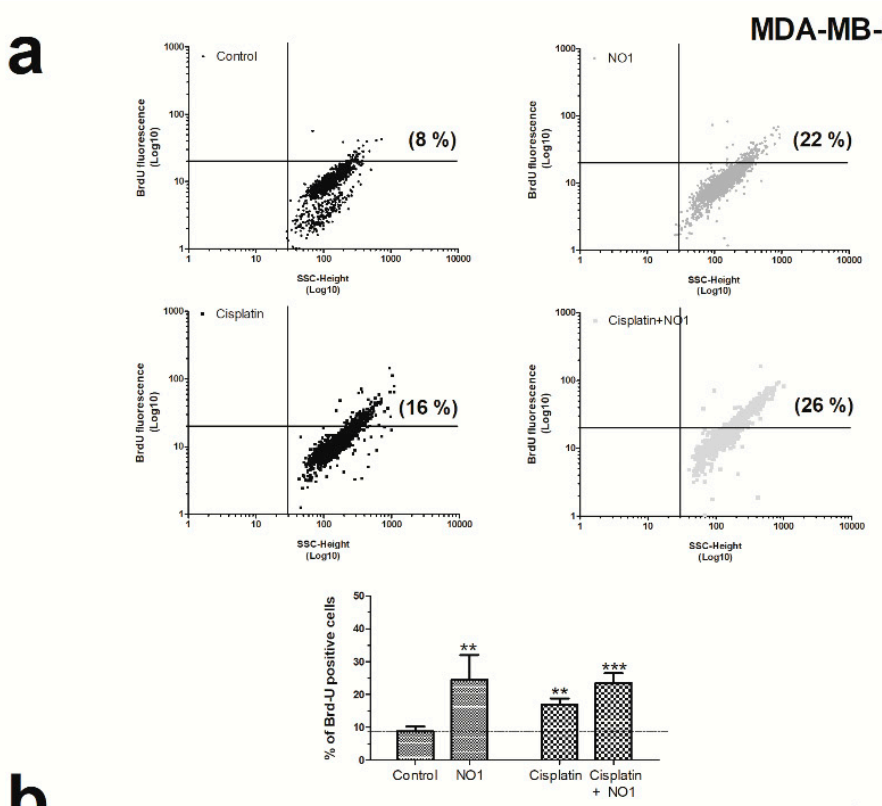

b
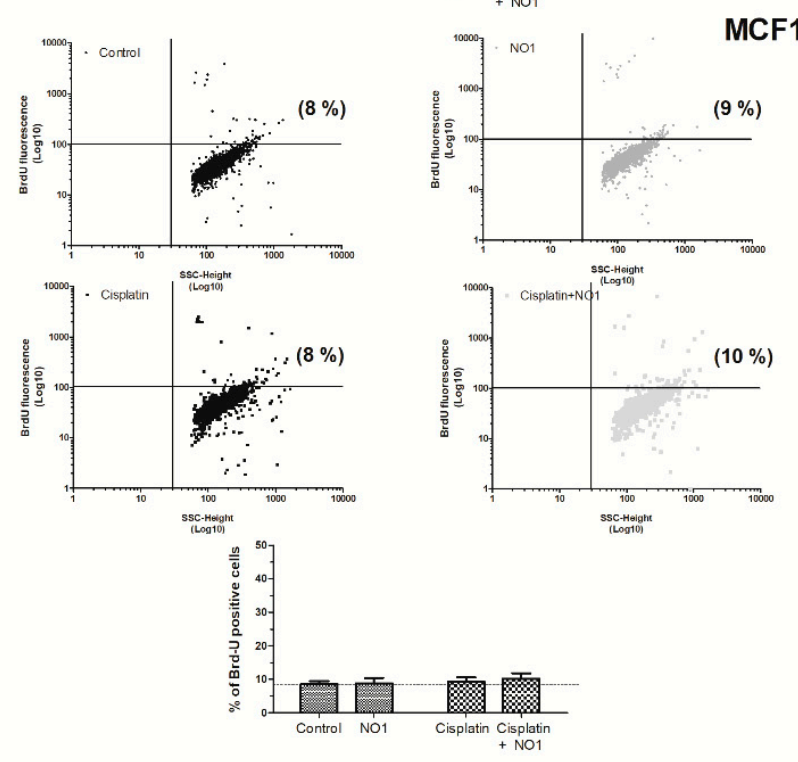

Figure 4. NO1 promotes apoptosis in MDA-MB-231 cells. MDA-MB-231 cells (a) and MCF10A (b) cells were treated with the $\sigma 2 \mathrm{R} / \mathrm{TMEM} 97$ ligand, NO1 (100 $\mathrm{nM}$ for $5 \mathrm{~min}$ ) or the antineoplastic drug, cisplatin ( $50 \mu \mathrm{M}$ for $30 \mathrm{~min})$ or a combination of both drugs. Once the incubation time with the drugs was over, the cells were fixed, and subsequently, BrdU-loading was achieved by following the instructions provided with the commercial apoptotic kit. The percentage of apoptotic cells was assessed using flow cytometry and the Flowing free software using the masks established for each of the cell populations. Dot-plots are representative of four different experiments, and histograms represent the mean \pm standard error of the mean (S.E.M.) of the percentage of positive BrdU stained cells after treatment with NO1 with respect the values found in the control cells. ${ }^{* *}$ and ${ }^{* * *}$ represent $p<0.01$ and $p<0.001$, respectively, compared to controls cells. 
a

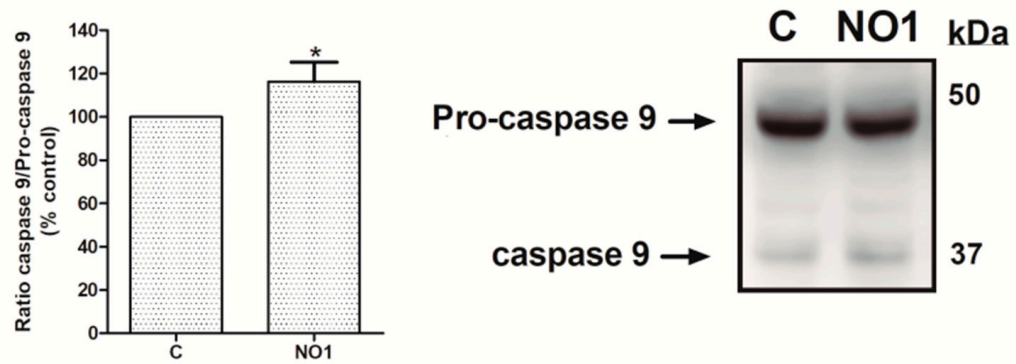

b
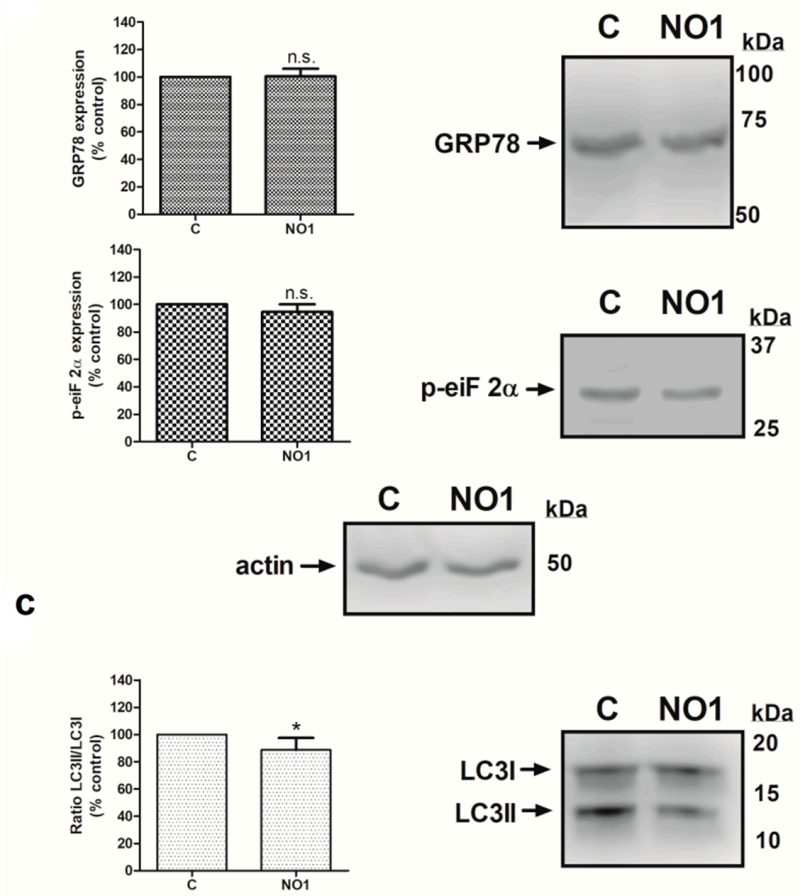

Figure 5. NO1 promotes the activation of caspase 9. MDA-MB-231 cells were stimulated with NO1 $(100 \mathrm{nM})$ for $5 \mathrm{~min}$, or were left untreated. Then, they were mixed with LB. Subsequently, Western blotting of the sample lysates was done using the anticaspase $9(\mathbf{a})$, antiphosphor-eiF2 $\alpha(\mathbf{b})$, anti-GRP78 (b), and anti-LC3 antibodies (c), as described in the Material and Methods section. Membranes were reprobed with actin-antibody as a loading control. Images are representative of four independent experiments, and histograms represent the average of the percentage \pm standard error of the mean (S.E.M.) of cells treated with the $\sigma 2 R$ agonist compared to nontreated control cells. ${ }^{*}$ represents $p<0.05$ compared to control cells, while n.s. represents $p>0.05$.

In addition, we evaluated the caspase pathways involved in the NO1-evoked apoptosis using the specific fluorogenic substrates for caspase 9, 3, and 8 [43]. As depicted in Figure S3, all of the used caspase substrates increased their fluorescence upon cell incubation with NO1 (100 nM). To ascertain possible interference derived of the NO1 autofluorescence in these results, we used internal controls where cells were incubated with NO1 but not with the fluorogenic substrates. We also added NO1 directly to the reaction buffer but lacking cell lysates. The resulting fluorescence obtained in these internal controls was used to correct the fluorescence emitted by the caspase substrates in each experiment. The magnitude of the fluorescence emitted by the caspase substrates were much greater than NO1 fluorescence. Data shown in Figure S3 revealed that caspase 9 would first be activated as a result of the NO1 incubation; this conclusion is based on the fact that a significant increase in the caspase 9 substrate fluorescence was evidenced as soon as $5 \mathrm{~min}$ after NO1 addition to the cells, which did not significantly change thereafter, independently of the incubation period (Figure S3a). The latter 
might be due to the interference with the mitochondrial activity previously reported when using other o2R/TMEM97 ligands [24]. Accordingly, caspase 3 was activated after incubating cells with NO1 for $5 \mathrm{~min}$, but to a smaller extent than caspase 9 (Figure S3b). The fluorescence of the caspase 3 and 8 substrates increased significantly after $30 \mathrm{~min}$ of cell incubation with NO1 (see Figure S3b,c). These caspases have been reported to be activated downstream of caspase 9 in other cell types [44]. Further evidence of the involvement of caspase 9 in the apoptotic mechanism driven by NO1 was obtained by preincubating the MDA-MB-231 cells for 90 min with $40 \mu \mathrm{M}$ of the caspase 9 inhibitor (Z-LEHD-FMK), which significantly attenuated the effect of NO1 (Figure S4).

\section{4. $\sigma 2 R / T M E M 97$ Is Required for SOCE Activation in MDA-MB-231 Cells}

Proliferation of breast tumor cells strongly depends on the $\mathrm{Ca}^{2+}$-homeostasis, as evidenced by the fact that silencing of Orai1, the main component of the store operated $\mathrm{Ca}^{2+}$ entry (SOCE), decreased the proliferation of the MDA-MB-231 cells [9,45]. In addition, calcineurin activation due to the $\mathrm{Ca}^{2+}$-entry through Orai1 has been reported to dephosphorylate and activate the proproliferative transcription factor NFAT1 [46,47]. Interestingly, the use of $\sigma 1 R$ and $\sigma 2 R$ ligands was shown to alter the $\mathrm{Ca}^{2+}$ homeostasis in SK-N-SH neuroblastoma cells [23]. Thus, considering the elevated expression of $02 \mathrm{R} / \mathrm{TMEM} 97$ in the MDA-MB-231 cells, we investigated its possible role in intracellular $\mathrm{Ca}^{2+}$ homeostasis. We observed that the incubation of fura-2-loaded MDA-MB-231 cells with NO1 (100 nM for $5 \mathrm{~min}$ ) did not produce significant changes in the TG-evoked $\mathrm{Ca}^{2+}$ release from the intracellular pools (Figure 6a). By contrast, NO1 significantly reduced SOCE by $17.0 \pm 12.0 \%$ (Figure $6 \mathrm{a} ; p<0.05$; $n=6$ ). NO1 was able to downregulate SOCE, even when this mechanism was previously activated due to cell stimulation with TG for $3 \mathrm{~min}$ before the addition of the $\sigma 2 \mathrm{R} / \mathrm{TMEM} 97$ ligand. As observed in Figure $6 \mathrm{~b}$, a reduction of $34.5 \pm 1.0 \%(p<0.001, n=6)$ was found under these experimental conditions. Interestingly, the preincubation of MDA-MB-231 cells for 5 min with SM21 overcame the inhibition of SOCE evoked by NO1 $(95.5 \pm 2.0 \% ; p>0.05, n=6)$. We further explored the role of $\sigma 2 \mathrm{R} / \mathrm{TMEM} 97$ in SOCE by either overexpressing TMEM97 (Figure $6 \mathrm{c}$ ) or by transfection of a siRNA TMEM97 (Figure 6d) in MDA-MB-231 cells. Upon confirming the transfection either by fluorescent microscopy or WB, TMEM97 overexpression resulted in an increase of $56.0 \pm 1.8 \%$ in SOCE $(p<0.001, n=4)$; meanwhile, silencing of TMEM97 reduced significantly the TG-evoked SOCE, i.e., by $24.8 \pm 14.5 \%(p<0.05, n=4)$.

a
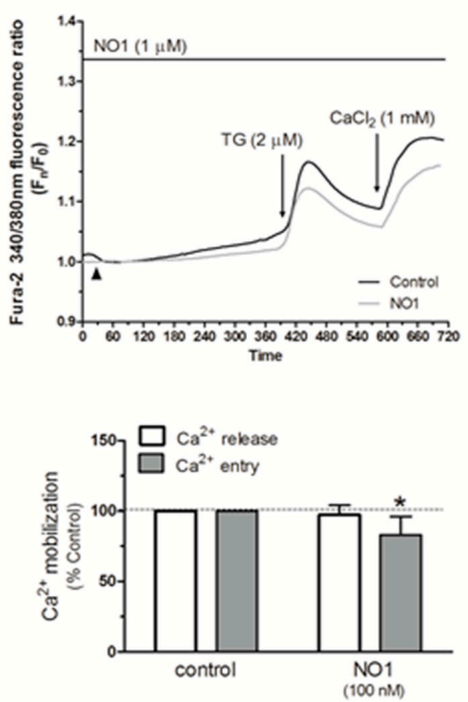

b
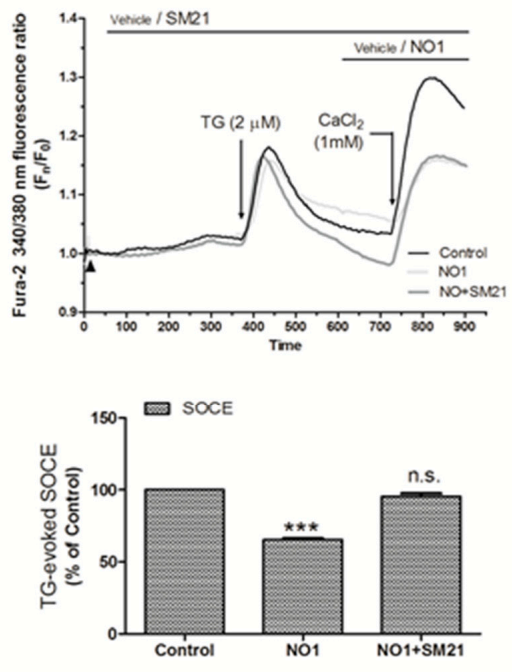

Figure 6. Cont. 

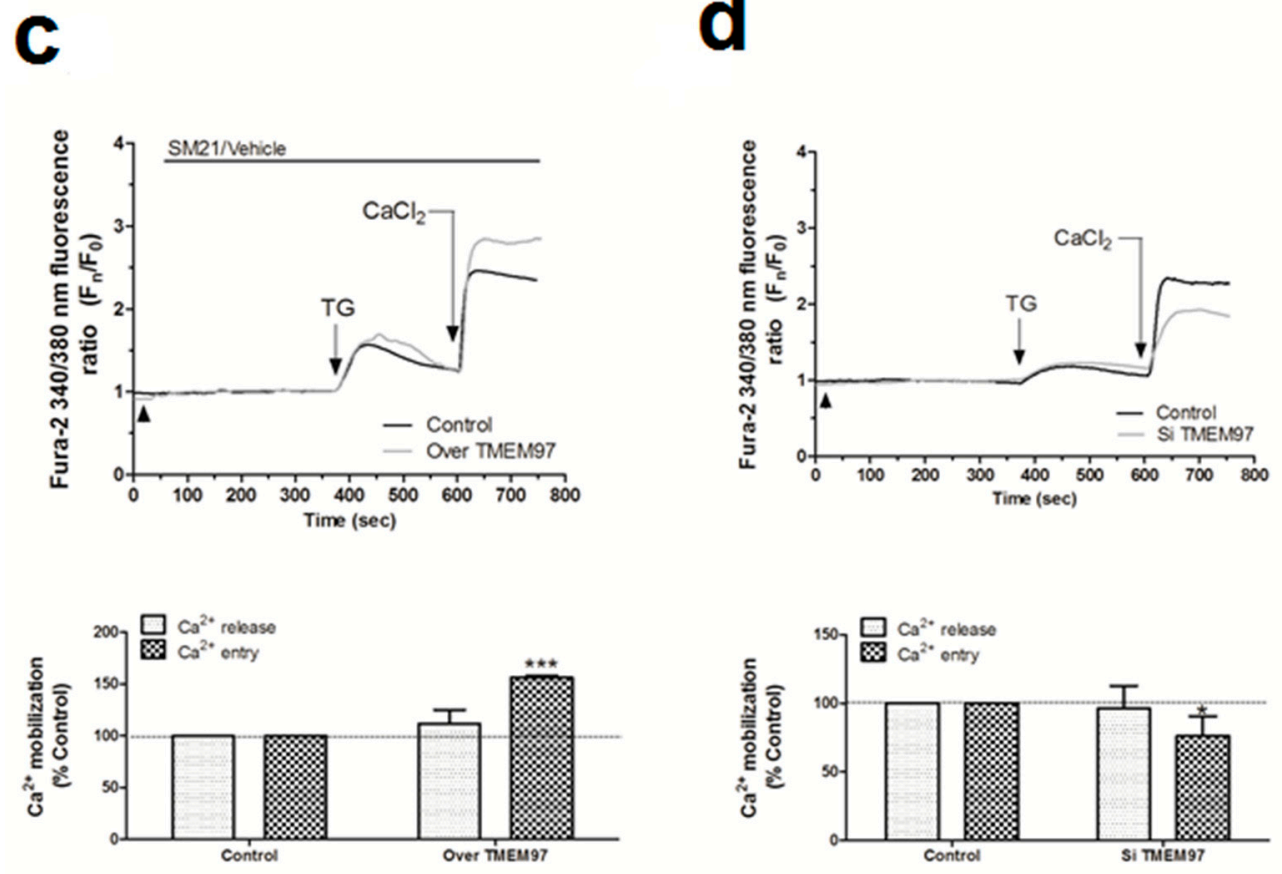

Figure 6. $\sigma \mathrm{R} / \mathrm{TMEM} 97$ is involved in the changes of $\mathrm{Ca}^{2+}$ homeostasis in MDA-MB-231 cells. MDA-MB-231 cells were allowed to grow on coverslips, and were loaded with fura-2/AM. They were subsequently maintained in an extracellular $\mathrm{Ca}^{2+}$-free HBS medium (containing $75 \mu \mathrm{M}$ of Ethylene Glycol Tetraacetic Acid (EGTA), arrowheads) and incubated with NO1 (100 nM, (a)) or SM21 (100 nM, (b)) or the vehicle, before stimulating store-operated calcium entry (SOCE) by adding thapsigargin (TG) $(2 \mu \mathrm{M},(\mathbf{a}))$. Alternatively, cells were supplemented with NO1 after the stimulation of SOCE with TG (b). Furthermore, MDA-MB-231 cells were genetically modified by overexpressing or silencing $\sigma$ R/TMEM97 $((\mathbf{c}, \mathbf{d})$, respectively), as described in the Material and Methods section. Cells were then loaded with fura-2/AM, and SOCE was activated by incubating with TG $(2 \mu \mathrm{M})$ for $4 \mathrm{~min}$. TG-evoked SOCE was monitored in all cases by supplementing the extracellular medium with $1 \mathrm{mM}$ of $\mathrm{CaCl}_{2}$. Changes of SOCE, evoked by incubating either with the $\sigma \mathrm{R} / \mathrm{TMEM} 97$ ligands or by genetic cell modification, were analyzed by determining the areas under the curves for $2 \mathrm{~min}$ after the addition of $\mathrm{CaCl}_{2}$. Graphs are representative of 6-8 independent experiments, and histograms represent the average of the percentage \pm standard error of the mean (S.E.M.) compared to cells nontreated with the $\sigma 2 \mathrm{R} / \mathrm{TMEM} 97$ ligands or nongenetically modified cells (control cells). * and ${ }^{* * *}$, represent $p<0.05$ and $<0.001$, respectively, with respect to the percentage found in control cells.

MCF10A cells expressed a very low amount of $\sigma 2 \mathrm{R} / \mathrm{TMEM} 97$ (see Figure 1). Therefore, we incubated cells with SM21 (100 nM for $5 \mathrm{~min}$ ) and, as expected, SM21 did not modify either the TG-evoked $\mathrm{Ca}^{2+}$ release from the intracellular stores or SOCE in these cell lines (See Figure S5a; $p>0.05, n=6)$. In contrast, in MDA-MB-231 cells that expressed a high amount of $\sigma 2 \mathrm{R} / \mathrm{TMEM} 97$, we observed an increase of $44.0 \pm 14.0 \%(p<0.001, n=8)$ in the TG-evoked Ca ${ }^{2+}$ entry after SM21 administration to MDA-MD-231 cells as compared to the values found in cells treated with the vehicle (See Figure S5b, $p<0,001, n=6$ ).

Interestingly, SM21 was unable to activate SOCE per se, suggesting that this $\sigma 2 \mathrm{R} / \mathrm{TMEM} 97$ ligand specifically regulates SOCE upon its activation with TG (Figure S5c). Elevated SOCE in the presence of SM21 could also be explained by a possible interference of $\sigma 2 \mathrm{R} / \mathrm{TMEM} 97$ with the plasma membrane Plasma membrane $\mathrm{Ca}^{2+}$-ATPase (PMCA) pumps, because we estimated SOCE by the determination of cytosolic $\mathrm{Ca}^{2+}$ concentrations, a parameter dependent on the balance between $\mathrm{Ca}^{2+}$ entry and $\mathrm{Ca}^{2+}$ clearing mechanisms [48,49]. In order to confirm this hypothesis, fura-2-loaded MDA-MB-231 cells were suspended in a $\mathrm{Ca}^{2+}$-free HBS medium and preincubated for 5 min with either the vehicle or SM21 
(100 nM), subsequently, with $2 \mu \mathrm{M}$ of TG (to block $\mathrm{Ca}^{2+}$ reuptake in the endoplasmic reticulum, ER) and $100 \mathrm{nM}$ of ionomycin (the $\mathrm{Ca}^{2+}$ ionophore used for facilitating the $\mathrm{Ca}^{2+}$ escape from intracellular stores). This protocol induced a transient increase in the cytosolic $\mathrm{Ca}^{2+}$ concentration. The $\mathrm{Ca}^{2+}$ decay constants were not altered in the absence and presence of SM21, and therefore, the changes observed in the $\mathrm{Ca}^{2+}$ extrusion rate derived from PMCA activity were not affected by $\sigma 2 \mathrm{R} / \mathrm{TMEM} 97$ activity (Figure S6). Finally, we preincubated the cells with PB28 for $5 \mathrm{~min}$ before activating SOCE with TG, which resulted in an increase of $57.9 \pm 27.5 \%$ and $51.6 \pm 21.5 \%$ in both the TG-evoked $\mathrm{Ca}^{2+}$ release and the TG-evoked SOCE, respectively. These findings suggest that $\sigma 2 \mathrm{R} / \mathrm{TMEM} 97$ is required for the activation of SOCE in MDA-MB-231 cells. We further explored the role of NO1 and SM21 in the association between the components of the SOCE, due to the fact that both specifically interfere with SOCE without affecting $\mathrm{Ca}^{2+}$ release, and furthermore, that both are very specific ligands of o2R/TMEM97. By contrast, the effects of PB28 could be explained by possibly off-target effects, since it is reported to bind $\sigma 1 \mathrm{R}$, and neither alters $\mathrm{Ca}^{2+}$ release nor SOCE in MCF7 (cell type expressing low $\sigma 1 R$ ) [32]. In fact, other authors have previously reported that this drug interferes with $\sigma 1 \mathrm{R}$ [50], which is highly expressed in MDA-MB-231 cells [51]. The latter would explain the fact that in our cell model, PB28 was observed to evoke $\mathrm{Ca}^{2+}$ release from intracellular stores, and, at the same time, to avoid the negative role of $\sigma 1 \mathrm{R}$ in SOCE that has recently been described in other cell types [52]; therefore, a PB28-dependent increase in SOCE would have a positive effect upon MDA-MB-231 cell proliferation, as presented above.

\section{5. $\sigma 2 R / T M E M 97$ Interacts with STIM1 But Not with Orai1 during SOCE Activation}

SOCE is driven by the interaction between the ER Ca ${ }^{2+}$ sensor, STIM1, and the specific $\mathrm{Ca}^{2+}$ channel, Orai1 [53-55]. Hence, we sought to determine whether $\sigma 2 R / T M E M 97$ might be interacting and regulating these key proteins during the activation of SOCE. Firstly, we explored the association between $\sigma 2 \mathrm{R} / \mathrm{TMEM} 97$ and STIM1 in MDA-MB-231 cells by immunoprecipitating the $\mathrm{Ca}^{2+}$ sensor with a specific anti-STIM1 antibody, followed by staining the immunoprecipitates with NO1, as described in the Material and Methods section. Analysis of the NO1 fluorescence revealed that TG enhanced the STIM1-o2R/TMEM97 interaction three fold (Figure 7a; $p<0.001, n=6$ ). Treatment of MDA-MB-231 cells with SM21 (5 min with $100 \mathrm{nM})$ reduced significantly this interaction $(p<0.001, n=6)$, which might explain why preincubation with SM21 prevents the effect of NO1 on SOCE, as described in Figure 6b.

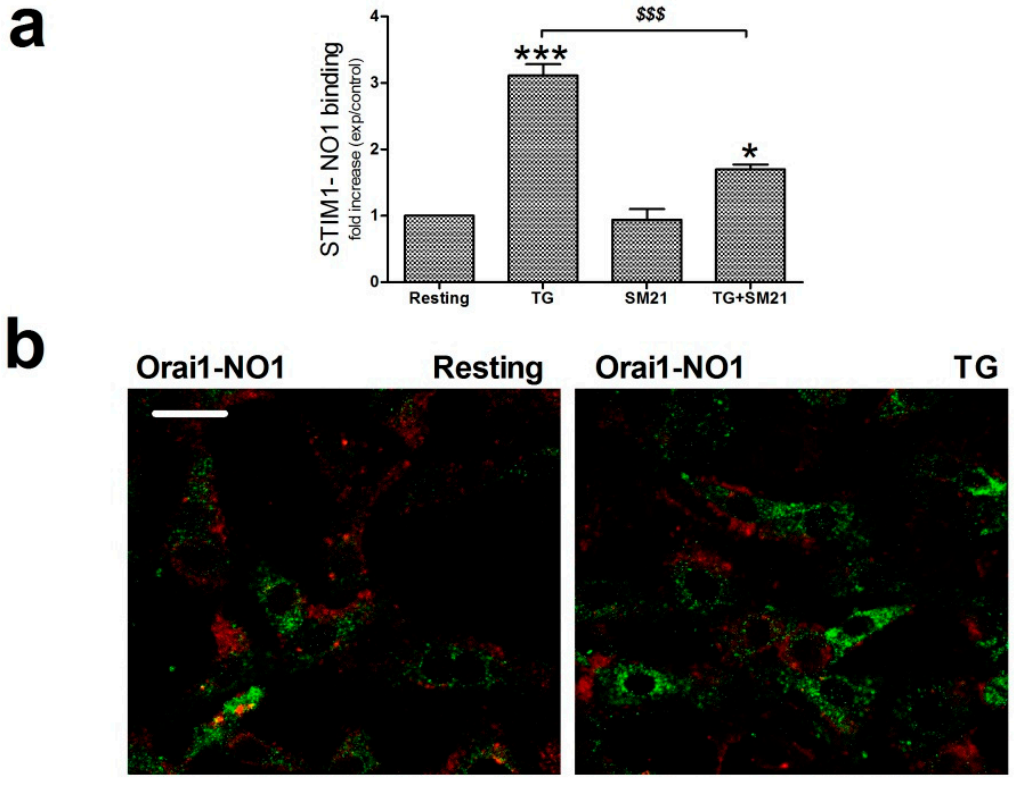

Figure 7. Cont. 


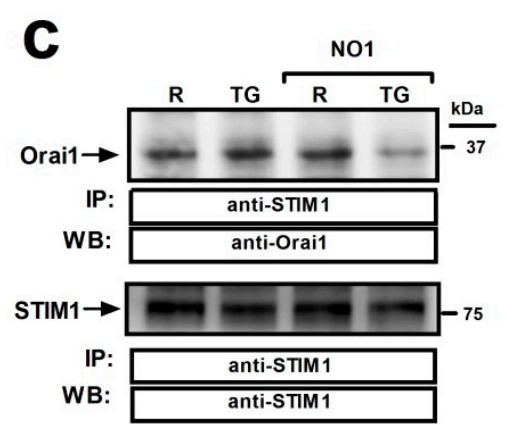

$\$ \$ \$$

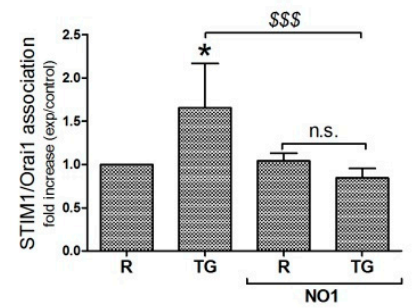

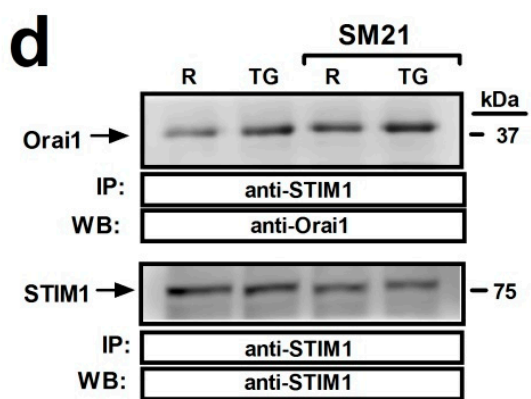

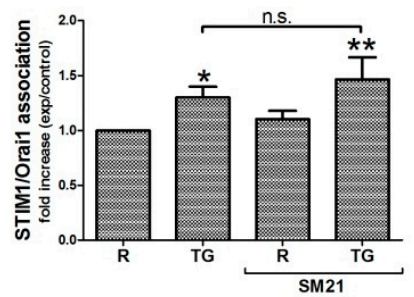

Figure 7. $\sigma 2 \mathrm{R} / \mathrm{TMEM} 97$ interacts with STIM1 but not with Orai1. (a) MDA-MB-231 cells suspended in $\mathrm{Ca}^{2+}$-free Hepes buffer saline (HBS) medium were left untreated or stimulated with thapsigargin (TG) $(2 \mu \mathrm{M})$ in the absence or presence of SM21 (100 nM). Next, they were fixed by mixing with an equal volume of NP40. Cell samples were immunoprecipitated using the specific anti-STIM1 antibody. On the following day, immunoprecipitated STIM1 complexes were suspended in PBS, and then incubated with $100 \mathrm{nM}$ of NO1 for $5 \mathrm{~min}$ in order to evaluate the amount of $\sigma 2 \mathrm{R} / \mathrm{TMEM} 97$ pulled down with STIM1. NO1 fluorescence in each cell batch was analyzed using a TECAN plate reader (390 nm/505 nm of Ex/Em). It was represented as a fold increase of the values of NO1 fluorescence found in resting cells. ${ }^{*}$ and ${ }^{* * *}$ : represent $p<0.05$ and $p<0.001$, respectively, compared to the resting cells; meanwhile, ${ }^{\$ \$}$ : represents $p<0.001$ respect cells nontreated with the $\sigma 2 \mathrm{R} / \mathrm{TMEM} 97$ ligands. (b) Orai1 and $\sigma 2 \mathrm{R} / \mathrm{TMEM} 97$ interaction was analyzed using confocal microscopy. Untreated cells or cells stimulated with TG ( $2 \mu \mathrm{M}$ for $1 \mathrm{~min})$ in a $\mathrm{Ca}^{2+}$-free HBS medium were then incubated for 5 min with NO1, and subsequently fixed by mixing with ice-cold paraformaldehyde. Then, cells were permeabilized (NP-40 buffer was used) and incubated with a bovine serum albumin (BSA) rich buffer (to avoid the antibodies' unspecific binding sites). Finally, the samples were incubated with an anti-Orai1 antibody. Visualization of Orai1 was achieved by using a Cy ${ }^{\mathrm{TM}} 3$ secondary fluorescent antibody following the protocol described in the Material and Methods. Fluorescent images of the cells were acquired using a confocal microscopy in order to analyze the colocalization. Bar represents $50 \mu \mathrm{m}$. (c) MDA-MB-231 cells were suspended in $\mathrm{Ca}^{2+}$-free HBS medium (75 $\mu \mathrm{M}$ EGTA was added) and incubated for $5 \mathrm{~min}$ with either the vehicle or NO1 ((c); $100 \mathrm{nM}$ for $5 \mathrm{~min})$, or with SM21 ((d); $100 \mathrm{nM}$ for $5 \mathrm{~min}$ ), after which they were left untreated (R: resting) or were incubated with TG ( $2 \mu \mathrm{M}, \mathrm{TG})$ for $1 \mathrm{~min}$ to stimulate store-operated calcium entry (SOCE), and then finally mixed with NP40 buffer. STIM1 was immunoprecipitated by incubating cell samples overnight with $2 \mu \mathrm{g} / \mathrm{mL}$ anti-STIM1 antibody and beads of agarose. The following day, immunoprecipitated STIM1 complexes were denaturalized by mixing with $L B$, and subsequently, WB, using a specific anti-Orai1 antibody, as described in the Material and Methods section. Reprobing of the membranes with the anti-STIM1 antibody was done as loading control. Images are representative of 6-10 independent WB experiments. Histograms represent the mean \pm standard error of the mean (S.E.M.) of the protein fold increase with respect the STIM1/Orai1 interaction found in resting cells. ${ }^{*}, * *$ : represent $p<0.05$ and $p<0.001$ respect to resting cells; $\$ \$ \$$ represents $p<0.001$ compared to cells nontreated with the $\sigma 2 \mathrm{R} / \mathrm{TMEM} 97$ ligands.

Previous data have suggested that $\sigma 2 \mathrm{R} / \mathrm{TMEM} 97$ might also be present in the plasma membrane of the cells, and may facilitate the transport of cholesterol toward the cytosol [26,56,57]; therefore, we further explored the possible interaction between $62 \mathrm{R} / \mathrm{TMEM} 97$ and Orai1 at this location. As depicted in Figure 7b, MDA-MB-231 cells were either stimulated with TG or left untreated, 
and subsequently, loaded for $5 \mathrm{~min}$ with NO1 (100 nM) before fixating with ice-cold paraformaldehyde. Subsequently, the Orai1 content was evaluated by staining the fixed cells with an anti-Orai1 antibody and a fluorescent secondary antibody. Confocal microscopy analysis revealed that $\sigma 2 R / T M E M 97$ did not colocalize, either in resting or in cells stimulated with TG (Figure 7b), with Orai1. Next, in order to ascertain whether $\sigma 2 \mathrm{R} / \mathrm{TMEM} 97$ plays a role in the interaction between STIM1 and Orai1, we tested the role of NO1 and SM21 in the co-immunoprecipitation between both proteins. As depicted in Figure 7c, treatment of MDA-MB-231 cells with TG enhanced the STIM1/Orai1 coupling by $1.6 \pm 0.6$-fold increase $(p<0.05 ; n=6)$. Preincubation with NO1 did not modify the interaction between the proteins in resting, but significantly reduced TG-evoked STIM1/Orai1 coupling $(0.85 \pm 0.1$-fold increase compared to the values found in resting cells; Figure 7c). In addition, treatment with SM21 (100 nM) for 5 min slightly enhanced the TG-evoked STIM1/Orai1 coupling, but the differences when compared with nontreated cells lacked statistical significance $(0.4 \pm 0.2 ; p>0.05, \mathrm{n}=8-10$; Figure $7 \mathrm{~d})$. Altogether, these results suggest that the addition of NO1 might downregulate $62 \mathrm{R} / \mathrm{TMEM} 97$ activity, and thus, NO1 may impair SOCE by affecting the interaction of the $\mathrm{I}_{C R A C}$ components, as was the case when we artificially silenced this protein using the siRNA against TMEM97 (Figure 6d).

Finally, to consolidate the latest results, we used the neuroblastoma NG115-401L cell line that expresses a scarce amount of STIM1 [58]. NG115-401L expressed TMEM97, and although it is significantly elevated with respect to the amount found in MCF10A cells, the values of TMEM97 found in NG115-401L were much smaller than those observed in MDA-MB-231 cells (Figure 8a). After $30 \mathrm{~min}$ of incubation with NO1 (100 nM), the NG115-401L cells presented low NO1 bioaccumulation, and consequently, exhibited a negligible NO1-derived fluorescence emission (see Video S3). This low bioaccumulation of NO1 may explain why these cells did not present significant changes in their morphology upon incubation with the drug for that time period, but also, it would explain the low PI staining (Figure 8a,c left-hand side images; NG115-401L mock) upon analysis of the cells by using the same protocol as in Figure 3. Additionally, the overexpression of STIM1 in this cell model reconstitutes normal SOCE, as previously evidenced by our research group and others $[59,60]$. Interestingly, STIM1 overexpression resulted in an increase in the NO1 intracellular redistribution in NG115-401L cells, which is parallel with an increase in the number of cells that are positively stained with PI (see Figure 8b dotted bar, and Figure 8c right-hand side images, NG115-401L STIM1). These results indicate that in the absence of STIM1, NO1 has less cytotoxic effect, thereby supporting the hypothesis that $\sigma 2 \mathrm{R} / \mathrm{TMEM} 97$ controls STIM1 and SOCE, as suggested by the elevated rate of colocalization between NO1 and STIM1 in NG115-401L cells where we previously overexpressed STIM1, followed by incubation for $30 \mathrm{~min}$ with NO1 (Figure S1b).
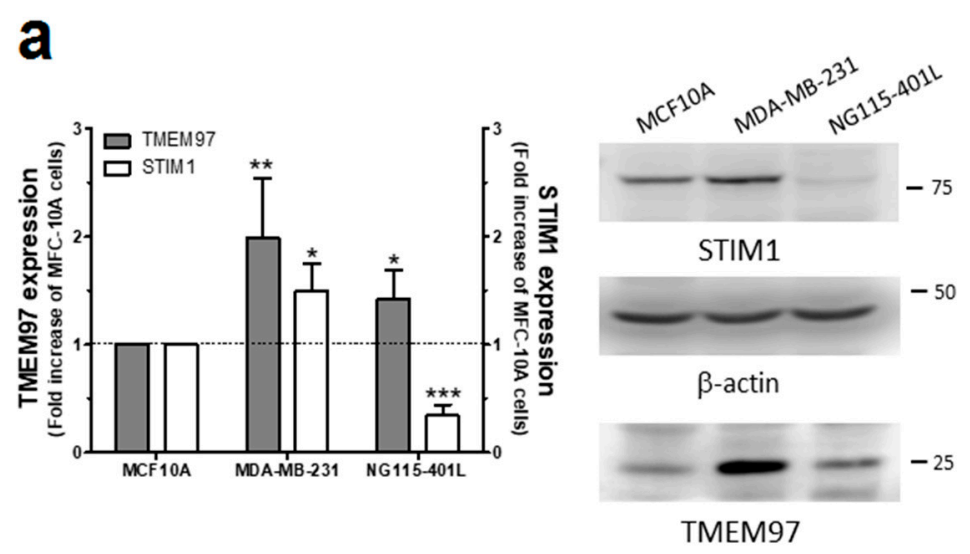

b

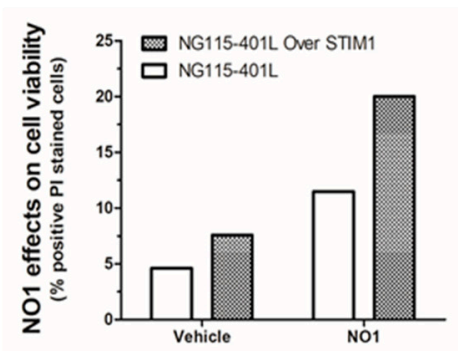

Figure 8. Cont. 


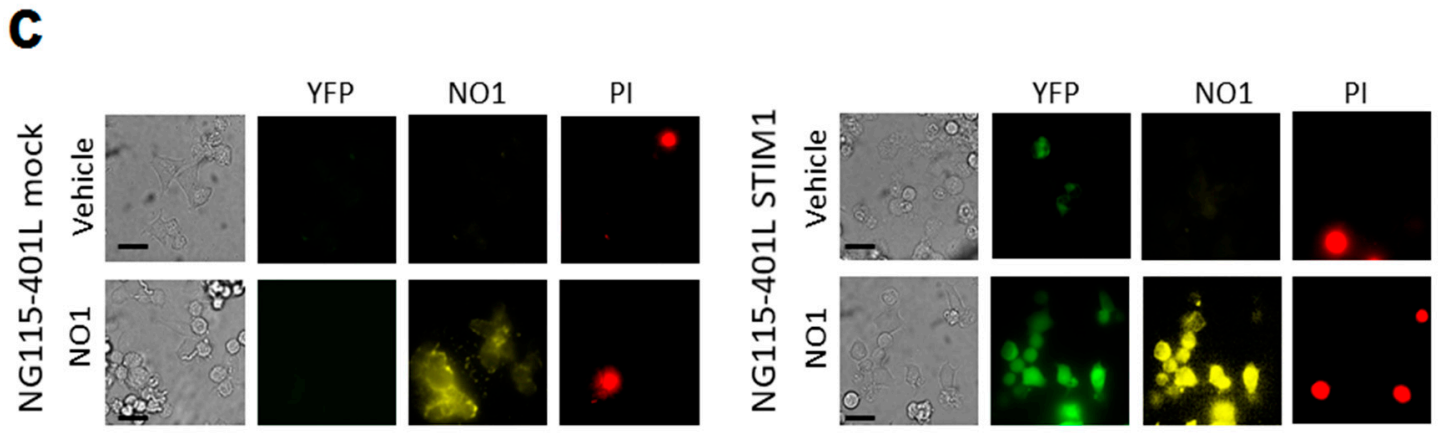

Figure 8. NO1 evoked cell death in NG115-401L artificially expressing STIM1. (a) MCF10A, MDA-MB-231, and NG115-401L cells growing under normal conditions were detached and suspended in different Phosphate buffer saline (PBS) buffers in order to obtain a similar number of cells $/ \mathrm{mL}$. Cells were then centrifuged and suspended in Laemmli's buffer and suggested to WB using anti-TMEM97 and anti-STIM1 antibodies as described in the Material and Methods section. The histogram represents the fold increase of STIM1 and o2R/TMEM97 expression values compared to those found in MCF10A upon normalization with actin, which was used as loading control. ****, and ${ }^{* * *}$ represent $p<0.05$, $<0.01$, and 0.001, respectively, with respect to the values found in MCF10A. (b,c) NG115-401L and NG115-401L overexpressing STIM1 were shed at the appropriated concentration, and after transfection was confirmed by fluorescent microscopy, cells were incubated for $45 \mathrm{~min}$ with propidium iodide (PI) in the incubator, and during the final $30 \mathrm{~min}$, the extracellular medium was supplemented either with the vehicle or with NO1 $(100 \mathrm{nM})$. When incubation time was over, cells were observed in the middle plane under an epifluorescent microscope using a 100x objective. (b) Histogram represents the percentage of positive PI stained cells upon treatment cells with NO1 vs. nontreated cells, for which results were derived by analyzing around 200 cells from four different independent transfections. Bars in the images represent $50 \mu \mathrm{m}$.

\section{Discussions}

In the present study, we examined the antiproliferative effect of NO1 in the triple negative breast cancer cell lines, MDA-MB-231 and MDA-MB-468 cells, and the downstream mechanisms of $62 \mathrm{R} / \mathrm{TMEM} 97$. Our results indicate that SM21 and PB28, both $\sigma 2 \mathrm{R} / \mathrm{TMEM} 97$ ligands, facilitate the proliferation and migration of MDA-MB-231 cells; by contrast, the addition of the NO1 impairs migration and evokes cell death by activating apoptosis via caspase 9 activation. Our results indicate that $\sigma 2 \mathrm{R} / \mathrm{TMEM} 97$ plays a regulatory role in SOCE, as TMEM97 overexpression enhances SOCE while TMEM97 silencing reduces it, as does NO1.

The inhibitory effect of NO1 on SOCE was consistent with its effect impairing STIM1/Orai1 interaction, and probably, by promoting the dissociation of the complex between $\sigma 2 \mathrm{R} / \mathrm{TMEM} 97$ and STIM1. As a result, NO1 administration to MDA-MB-231 cells evoked a reduction in cell proliferation and migration that agrees with previous investigations reported in the literature using other ligands of б2R/TMEM97 [17,18,36,61]. In line with our observations, $\sigma 2 R / T M E M 97$ was shown to be overexpressed in different cancer types, and even in patients with breast cancer $[31,62,63]$. Here, we confirmed the enhanced $\sigma 2 \mathrm{R} / \mathrm{TMEM} 97$ expression in the triple negative breast cancer cell line MDA-MB-231 cells by different experimental approaches.

A possible regulatory role of $\sigma 2 \mathrm{R} / \mathrm{TMEM} 97$ in the intracellular $\mathrm{Ca}^{2+}$ homeostasis has already been suggested in the human neuroblastoma cells, SK-N-SH cell line, using high concentrations of ligands BD737 and CB-64D [23]. However, according to the pharmacological drug profiles described by these authors, $\sigma 1 \mathrm{R}$ might also be affected by these drugs at the concentration used [23]. It is worth noting that those $\sigma 2 \mathrm{R} / \mathrm{TMEM} 97$ ligands failed to release $\mathrm{Ca}^{2+}$ when the $\mathrm{Ca}^{2+}$ stores were previously depleted with TG, indicating that the $\mathrm{Ca}^{2+}$ source is the ER, leading us to again assume that $\sigma 1 \mathrm{R}$ might be involved in this process. In fact, $\sigma 1 \mathrm{R}$ was localized in the mitochondrial-associated membranes complexes, and subsequently, may regulate $\mathrm{Ca}^{2+}$ depletion from the ER and mitochondrial 
overload [64]. Furthermore, it has been shown that $\sigma 1 R$ associates with STIM1 in the ER, thereby acting as its negative regulator, which would explain the negative role of $\sigma 1 \mathrm{R}$ in SOCE. We found here that among the $\sigma 2 R / T M E M 97$ ligands used in MDA-MB-231 or MCF10A (in case of SM21), two of them, SM21 and NO1, failed to evoke $\mathrm{Ca}^{2+}$ release from the intracellular $\mathrm{Ca}^{2+}$ stores at the concentrations assayed (100 nM) [65]. In addition, the o2R/TMEM97 ligand, NO1, did not alter the $\mathrm{Ca}^{2+}$ content within the intracellular stores of MDA-MB-231 cells, which disagrees with the results obtained using the F281 ( $\sigma 2 \mathrm{R}$ agonist) in SK-N-SH cells [24]. According to the latter, it is likely that $\sigma 2 \mathrm{R} / \mathrm{TMEM} 97$ has different roles in different cell lineages. In fact, a similar dual role of $\sigma 1 \mathrm{R}$ in $\mathrm{Ca}^{2+}$ homeostasis can be found in the literature; thus, although $\sigma 1 \mathrm{R}$ has been shown to be a negative regulator of SOCE in SK-N-SH cells, other authors have demonstrated that the addition of the $\sigma 1 \mathrm{R}$ agonist, pentazocine, enhanced SOCE in SK-N-SH and MCF7 (artificially overexpressing $\sigma 1 \mathrm{R}$ ) cell lines, while BD1063 ( $\sigma 1 \mathrm{R}$ antagonist) reduced $\mathrm{Ca}^{2+}$ entry. Similarly, PB28 did not promote SOCE in MCF7, but this $62 \mathrm{R} / \mathrm{TMEM} 97$ ligand enhanced SOCE in MDA-MB-231 cells which can be explained by the elevated $\sigma 1 \mathrm{R}$ content in these cells, compared to those of MCF7, that express a low amount of o1R [66]. Enhanced SOCE evoked by PB28 could be explained by the dual role of the drug over $\sigma 1 \mathrm{R}$ and $\sigma 2 \mathrm{R} / \mathrm{TMEM} 97$. While activating $\sigma 2 \mathrm{R} / \mathrm{TMEM} 97$, a positive regulator of SOCE, it is simultaneously inhibiting the SOCE negative regulator, $\sigma 1 R$, which would result in the exacerbated SOCE demonstrated in Figure S5d, and in the enhanced proliferation shown in Figure 2b. Similarly, SM21 might be activating SOCE, despite the fact that a slight increase in the interaction between STIM1 and Orai1 was demonstrated (Figure 7d). In line with this latter observation, SM21 would increase MDA-MB-231 cell proliferation. In contrast, NO1 would downregulate SOCE by interacting with $\sigma 2 \mathrm{R} / \mathrm{TMEM} 97$, and perhaps also by impairing its association with STIM1. Although speculative, $62 \mathrm{R} / \mathrm{TMEM} 97$ might displace $\sigma 1 \mathrm{R}$ from STIM1, thus favoring its interaction with Orai1, which would be a worthy object of future research.

In the breast cancer cell lines MCF7 and MDA-MB-231 cells, the silencing of Orai3 and Orai1 expressions reduced cell proliferation and tumorigenic properties $[4,9,10,45]$. In the present study, we report for the first time that a ligand of o2R/TMEM97, NO1, enhanced MDA-MB-231 cell death and reduced the TNBCs proliferation and migration. Our results agree with previous publications regarding other $\sigma 2 \mathrm{R} / \mathrm{TMEM} 97$ ligands, such as WC-26, SV119, and RHM-138, that were shown to evoke cell death of the EMT-6 and MDA-MB-435 cell lines [26]. The authors claimed that these $62 \mathrm{R} / \mathrm{TMEM} 97$ agonists induced both mitochondrial-dependent apoptosis and the activation of autophagy, which occurs through the synthesis and processing of LC-3, subsequently reducing mTOR expression [26]. In MDA-MB-231 cells, NO1 does not evoke the activation of autophagy, as concluded by the fact that no significant changes in the LC3I/LC3I ratio were observed (see Figure 5). Finally, in order to determine the mechanism through which $\sigma 2 \mathrm{R}$ activity might impair breast cancer cell survival, we analyzed its possible localization within the mitochondria. $62 \mathrm{R} / \mathrm{TMEM} 97$ activation might mobilize $\mathrm{Ca}^{2+}$ from mitochondria [24] and evoke mitochondrial membrane potential uncoupling and caspase-dependent apoptosis activation, as previously reported $[18,24]$. By using confocal microscopy and the fluorescent б2R/TMEM97 ligand (NO1), we failed to localize this protein within the mitochondria, either under resting conditions or during SOCE activation with TG. Nonetheless, NO1 was able to induce procaspase 9 cleavage into the active caspase 9 (Figure 5a and Figure S3). Caspase 9 activation is widely used as a cell marker to monitor the activation of mitochondria-dependent apoptosis $[67,68]$; this observation agrees with previous ones using $62 \mathrm{R} / \mathrm{TMEM} 97$ agonists [17]. In this sense, the $\sigma 2 \mathrm{R}$ agonist (F281) reduces ATP concentration in a time- and concentration-dependent manner in SK-N-SH cells, which has been attributed to its ability to interfere with the mitochondrial function, and subsequently, to attenuate ATP synthesis [24]. The regulation of SOCE by the mitochondria and vice versa have been widely described [69-71]. Therefore, o2R/TMEM97 may facilitate SOCE by two different mechanisms, firstly facilitating STIM1 activation, and subsequently, favoring its contact to Orai1, but it may also enhance mitochondrial function, which would lead to mitochondrial $\mathrm{Ca}^{2+}$-sequestering in the proximity of the channel in the membrane that has been reported to delay the signaling of SOCE downregulation by $\mathrm{Ca}^{2+}[72-74]$. It is worth noting that in NG115-401L, a model mostly lacking STIM1, NO1 was 
unable to evoke cell death unless STIM1 was overexpressed, which reinforces our presumption that STIM1 is an intracellular target of NO1. In line with this observation, we suggest that the expression of STIM1 and $\sigma 2 R / T M E M 97$ may be indicative of the efficiency of the NO1 in impairing the progression of certain types of cancers, but further experiments are required to confirm this idea. The inhibition of б2R/TMEM97 in both TNBC leads to the induction of apoptosis and the reduction of cell proliferation, thus supporting the relevance of this protein in the physiology of triple negative breast cancer cells.

In summary, we described an elevated o2R/TMEM97 expression in MDA-MB-231 cells, which might be involved in the regulation of cell proliferation through the enhancement of SOCE (see Figure 9). NO1 impairs the role of $\sigma 2 \mathrm{R} / \mathrm{TMEM} 97$ in SOCE, thus evoking MDA-MB-231 cell death.

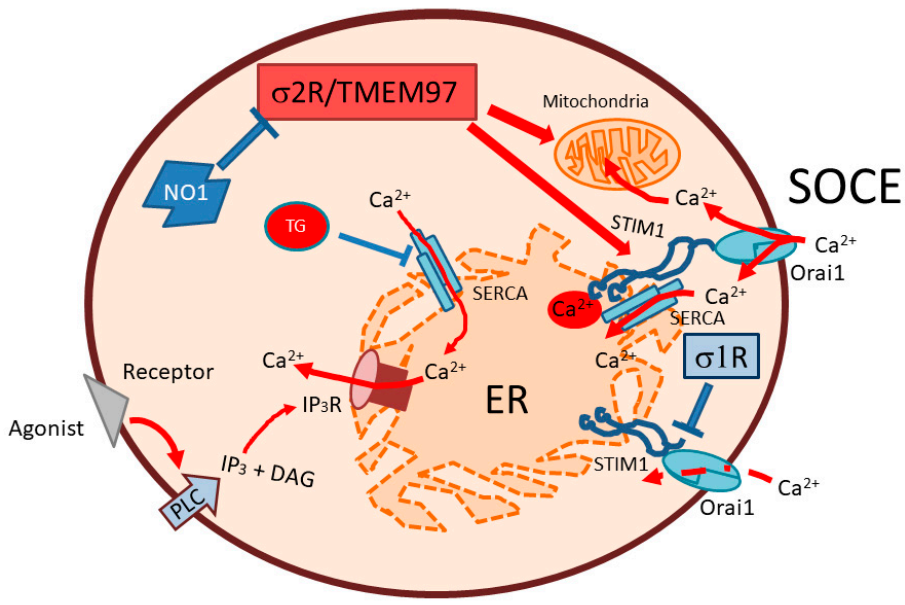

Figure 9. Schematic representation of the $62 \mathrm{R} / \mathrm{TMEM} 97$ regulation of SOCE in MDA-MB-231. SOCE activation in MDA-MB-231 cells may be positively regulated by $\sigma 2 \mathrm{R} / \mathrm{TMEM} 97$, due to its interaction with STIM1, thereby facilitating its coupling with Orai1. Enhanced SOCE may favor mitochondrial function and cell ATP content, which may lead to enhanced cell proliferation. In contrast, o2R/TMEM97 inhibition by NO1 administration may block both SOCE, and may disrupt mitochondria, subsequently activating apoptosis through caspase 9. SOCE: store operated $\mathrm{Ca}^{2+}$ entry; PLC: phospholipase $\mathrm{C}_{;} \mathrm{IP}_{3}$ : inositol trisphosphate; DAG: diacylglycerol; $\mathrm{IP}_{3} \mathrm{R}$ : inositol trisphosphate receptor. ER: endoplasmic reticulum; SERCA; sarconendoplasmic reticulum $\mathrm{Ca}^{2+}$ ATPase; TG: thapsigargin.

\section{Material and Methods}

\subsection{Reagents}

б2R ligands (SM21 maleate and PB28) were obtained from Tocris ${ }^{\circledR}$ (Bio-techne brand, Madrid, Spain). The o2R/TMEM97 fluorescent ligand NO1 (2-\{6-[2-(3-(6,7-dimethoxy-3,4-dihydroisoquinolin-2 (1H)-yl)propyl)-3,4-dihydroisoquinolin-1(2H)-one-5-yloxy]hexyl\}-5-(dimethylamino)indoline-1,3-dione) was produced by Dr. C Abate [30]. Fura-2/AM, mitotracker-red and propidium iodide (PI) were obtained from ThermoFisher Scientific (Molecular Probes ${ }^{\circledR}$, Madrid, Spain). Anti-STIM1 antibody was obtained from BD-bioscience ${ }^{\circledR}$ (Madrid, Spain). Anti-TMEM97 antibody, siRNA against TMEM97 and the overexpression plasmid of TMEM97 were purchased from Origene@ (Rockville, MD, USA). STIM1 overexpression plasmid was kindly provided by Dr. Cristoff Romanin (Johannes Kepler University (JKU), Linz, Austria). Antiphosphor-eif 2 $\alpha$, anticaspase-9, anti-LC3 antibody were purchased from Cell signalling ${ }^{\circledR}$ (Leiden, The Netherlands). Cy ${ }^{\mathrm{TM}} 3$ affiniPure goat antirabbit IgG antibody and other HRP-conjugated secondary antibodies were obtained from Jackson Immunoresearch Europe Ltd. (Cambridge, UK). The BrdU-apoptotic Kit was purchased from Abcam ${ }^{\circledR}$ (Cambridge, UK), while the BrdU cell proliferation assay kit was obtained from BioVision Inc. (Milpitas, CA, USA). Anti-Orai1 antibody, thapsigargin (TG), and caspase 3, 8, and 9 fluorogenic substrates, as well as, other reagents of analytical grade were purchased from Sigma-Aldrich ${ }^{\circledR}$ (Madrid, Spain). 


\subsection{Cell Culture}

ER+ breast cancer cell line (MCF7), the triple negative cell lines (MDA-MB-231 and MDA-MB-468), the nontumoral cell line (MCF10A) and the rat-mice neuroblastoma cell lacking STIM1 (NG115-401L) were purchased from ATCC ${ }^{\circledR}$ Europe and cultured following the manufacturer's instructions. Briefly, MCF7, MDA-MB-231, MDA-MB-468, and NG115-401L cells were cultured at $37^{\circ} \mathrm{C}$ with $5 \% \mathrm{CO}_{2}$ in DMEM medium supplemented with FBS and penicillin/streptomycin; meanwhile, MCF10A were cultured in Dulbecco's Modified Eagle Medium (DMEM) F-12 supplemented with horse serum, insulin, hydrocortisone, epidermal growth factor (EGF), cholera toxin, and penicillin/streptomycin.

\subsection{Measurement of Cytosolic Free-Ca ${ }^{2+}$ Concentration}

MCF10A and MDA-MB-231 cells were shed $\left(1 \times 10^{6}\right.$ cells $\left./ \mathrm{mL}\right)$ and grown for $24 \mathrm{~h}$ onto coverslips. On the day of the experiments, cells were incubated with fura-2/AM for $30 \mathrm{~min}$ at room temperature, and then were placed inside a perfusion chamber containing a $\mathrm{Ca}^{2+}$-free $\mathrm{HBS}$ medium (containing in mM: $145 \mathrm{NaCl}, 10$ HEPES, 10 D-glucose, $5 \mathrm{KCl}, 1 \mathrm{Mg}_{2} \mathrm{SO}_{4} ; \mathrm{pH} 7.40$ ). Next, $50 \mu \mathrm{M}$ of $\mathrm{CaCl}_{2}$ was added in order to avoid intracellular $\mathrm{Ca}^{2+}$-pools depletion derived from cell manipulation. The perfusion chambers were mounted under a fluorescent inverted microscope (Nikon ${ }^{\circledR}$, Nikon Eclipse Ti2, Amsterdam, The Netherlands) where cells were kept under resting conditions for 5-10 min. Cells were alternatively excited at a wavelength of 340/380 $\mathrm{nm}$ during stimulation with required solutions, as indicated. Fura- 2 emission was acquired at $515 \mathrm{~nm}$ of wavelength using a cooled digital CCD camera (Hisca CCD C-6790, Hamamatsu, Japan), and using the Aquacosmos 2.5 software (Hamamatsu Photonics, Hamamatsu, Japan). The resulting traces were normalized with respect to the fluorescence emitted by the cells under resting conditions $\left(\mathrm{F}_{\mathrm{n}} / \mathrm{F}_{0}\right)$ [2]. Cells were temporarily maintained in a $\mathrm{Ca}^{2+}$-free HBS (EGTA was added, $75 \mu \mathrm{M}$ ), and subsequently, $2 \mu \mathrm{M}$ of TG was administered to evoke the depletion of the intracellular $\mathrm{Ca}^{2+}$ stores. The resulting SOCE was visualized by adding of $1 \mathrm{mM} \mathrm{CaCl}_{2}$ to the extracellular medium, and the area under the curves was estimated for $2 \mathrm{~min}$ in order to compare the possible differences among the different experimental conditions. Additionally, to determine the changes in the activity of the plasma membrane $\mathrm{Ca}^{2+}$-ATPase pump (PMCA), fura-2-loaded MDA-MB-231 cells were stimulated with TG $(2 \mu \mathrm{M})+$ ionomicin $(500 \mathrm{nM})$ in the absence of extracellular $\mathrm{Ca}^{2+}$, as described elsewhere [48]. The decay constants (D) of the resulting traces were calculated using the GraphPad 5.0 software.

\subsection{Immunoprecipitation and Western Blotting}

MDA-MB-231 cells were treated for 5 min with the o2R/TMEM97 ligands, NO1, or SM21, or remained untreated. SOCE was subsequently stimulated for $1 \mathrm{~min}$ using $2 \mu \mathrm{M}$ of TG in a $\mathrm{Ca}^{2+}$-free HBS, or the cells remained under resting condition. Additionally, the other cell lines were cultured under normal conditions, and upon collecting $1 \times 10^{6} \mathrm{cells} / \mathrm{mL}$, were fixed and lysed under resting conditions by mixing with an equal amount of ice-cold NP40 buffer $(\times 2)$. Cell lysates were subjected to the immunoprecipitation that resulted from incubating cell sample lysates overnight at $4{ }^{\circ} \mathrm{C}$ with $30 \mu \mathrm{L}$ of beads of agarose and $3 \mu \mathrm{g}$ of anti-STIM1 antibody. Alternatively, proteins were denaturalized by mixing the NP40 buffer with an equal volume of Laemmli's buffer under reducing conditions ( $5 \%$ final concentration of dithiothreitol (DTT) was added). Immunoprecipitated complexes were denaturalized as mentioned above, and were solved by performing subsequent Western blotting using a $10 \%$ sodium dodecyl sulphate (SDS)-page. Isolated proteins were electrotransferred onto nitrocellulose membranes that were subsequently incubated with a blocking buffer for $1 \mathrm{~h}$. After this, they were exposed to the specific anti-Orai1 antibody for $2 \mathrm{~h}$ at room temperature (diluted 1:500 in blocking buffer) in the case of the immunoprecipitated samples, and to a specific anti-TMEM97 antibody for $2 \mathrm{~h}$ at room temperature (1:500 in blocking buffer) in the case of the WB samples. Removal of the excess of primary antibodies was done by washing the membranes with tris-buffered saline supplemented with Tween 20 (TBST) for $30 \mathrm{~min}$. Membranes were then incubated with the appropriated HRP-conjugated IgG anti mouse 
antibody for $1 \mathrm{~h}$ (diluted 1:10,000 in TBST). Finally, membranes were exposed to a chemiluminescent solution (Dura ECL solution from Pierce ${ }^{\circledR}$, Thermofisher, Madrid, Spain) for 10 min. The emitted light was measured using the C-DIGIT (Licor ${ }^{\circledR}$ Biosciences, Lincoln, NE, USA) densitometer, and the images were analyzed using the Image J software.

Additionally, we evaluated the activation of different cell death mechanisms in MDA-MB-231 cells by Western blotting. Thus, ER stress was determined by changes in the expression of GRP78 (anti-GRP78 antibody diluted 1:500 for $2 \mathrm{~h}$ ) and by analyzing the values of phosphorylation of the transcription factor eiF2 $\alpha$ (antiphospho-eiF2 $\alpha$ diluted 1:1000 for $2 \mathrm{~h}$ ). On the other hand, activation of the autophagy was analyzed by considering the ratio between LC3I and LC3II (anti-LC3 antibody diluted 1:1000 overnight), as described elsewhere [75]. Finally, an analysis of the activation of the mitochondrial-dependent apoptotic pathway was done by evaluating the conversion of the inactive procaspase 9 on active caspase 9 (anticaspase 9 antibody diluted 1:10,000 overnight). Upon washing, the primary antibodies and membranes were incubated with the appropriate secondary antibody. Finally, the membranes were developed as indicated above.

\subsection{NO1 Uptake Analysis Confocal Microscopy, and Intracellular o2R/Orai1 Colocalization}

MCF10A, MCF7, and MDA-MB-231 cells were shed onto a coverslip and covered with phosphate buffer saline (PBS); thereafter, cells were incubated for $5 \mathrm{~min}$ with $100 \mathrm{nM}$ of $\mathrm{NO} 1$ alone or in combination with mitotracker-red $(2 \mu \mathrm{M})$ for $2 \mathrm{~min}$. Subsequently, cells were kept under resting condition or stimulated for 2 min with TG $(2 \mu \mathrm{M})$. Stained cells were washed twice with PBS and observed under a Nikon fluorescent confocal microscope using wavelengths of 390/505 and 581/644 nm (Ex/Em) to observe NO1 or mitotracker-red, respectively. Images were focused at the middle-cell plane, with the same exposure time in each experimental condition, using a 40x-immersion oil objective. Images were acquired using the NIS image software that controls an Eclipse TE300 fluorescence microscope (Nikon Corporation, Tokyo, Japan).

Breast cancer cell lines (MCF7 and MDA-MB-231 cells) and the nontumoral proliferative breast cell line (MCF10A) were incubated for $5 \mathrm{~min}$ with NO1 (100 nM). Once the incubation time was over, cells were washed with PBS solution in order to remove the excess NO1 that had not been internalized by the cells. Following this, cells were detached and counted. Upon normalizing the number of cells in each sample, they were loaded into a quartz cuvette and placed inside a spectrofluorophotometer holder. Next, NO1-emitted fluorescence was analyzed by exciting the samples at $390 \mathrm{~nm}$, and the emitted fluorescence was subsequently recorded at $505 \mathrm{~nm}$. The fluorescence emitted by the MCF10A cell batches was considered to be $100 \%$, and those of the other cell types were expressed relative to this benchmark.

In order to ascertain the possible changes in the main channel involved in SOCE, Orai1, due to б2R/TMEM97 dysregulation by NO1, MDA-MB-231 cells were loaded with anti-Orai1 antibody and NO1 as described below. Briefly, MDA-MB-231 cells were shed onto a coverslip $\left(0.5 \times 10^{6}\right.$ cells $\left./ \mathrm{mL}\right)$. At the day of the experiment, DMEM medium was replaced by $\mathrm{Ca}^{2+}$-free HBS (containing $75 \mu \mathrm{M}$ of EGTA) and incubated for $5 \mathrm{~min}$ with $100 \mathrm{nM}$ of NO1. SOCE was then stimulated for 1 min with $2 \mu \mathrm{M}$ of TG, or the cells remained under resting conditions. Next, cell fixation was done by incubating at room temperature for 30 min with $4 \%$ of paraformaldehyde. Cells were then washed with PBS, and permeabilized by incubation with PBS + Triton-X100 (0.1\%) for $30 \mathrm{~min}$. Nonspecific binding sites were blocked with the Blocking solution (PBS + Triton X-100 supplemented with 5\% of BSA), and cell samples were incubated with anti-Orai1 antibody for $1 \mathrm{~h}$ at room temperature (diluted 1:200 in the blocking solution). Excess primary antibodies were removed by washing three times with fresh PBS. Afterwards, samples were incubated in the dark for an additional $30 \mathrm{~min}$ with the fluorescent secondary antibody (Cy ${ }^{\mathrm{TM}} 3$ AffiniPure Goat Anti-Rabbit IgG antibody (1:50 in blocking solution). Coverslips were washed once more with PBS, as previously indicated, and mounted using a glycerol-based solution (PBS $+80 \%$ of glycerol). Cell preparations were observed under fluorescent confocal microscopy ( $\times 40$ magnification objective), and images were acquired using the adequate excitation and emission 
wavelengths (380/505 nm and 512/615 nm the maximum Ex/Em wavelength for the NO1 and Cy3, respectively). The colocalization index was analyzed using the NIH free-software Image J.

\section{6. o2R/STIM1 Coupling Detection}

The association between $\sigma 2 \mathrm{R} / \mathrm{TMEM} 97$ and STIM1 was analyzed by using a TECAM plate reader and the following protocol. MDA-MB-231 cells $\left(4 \times 10^{6}\right.$ cells $\left./ \mathrm{mL}\right)$ were suspended in $\mathrm{Ca}^{2+}$-free HBS (75 $\mu \mathrm{M}$ of EGTA was used), and then incubated for $5 \mathrm{~min}$ with the $\sigma 2 \mathrm{R} / \mathrm{TMEM} 97$ ligand, SM21, or left untreated. SOCE was stimulated by adding $2 \mu \mathrm{M}$ of TG, or was kept under resting conditions The reaction was stopped by mixing the cells with an equal volume of ice-cold NP40 buffer $(\times 2)$ (containing in mM: 20 Tris- $\mathrm{HCl}, 1.37 \mathrm{NaCl}, 2$ EDTA, 10\% glycerol and 1\% Nonidet P-40; pH 8.0). Samples containing protein complexes were then subjected to the immunoprecipitation protocol described above. The STIM1/O2R/TMEM97 complexes were immunoprecipitated using the specific anti-STIM1 antibody, and were stained by incubating the immunoprecipitated samples with $100 \mathrm{nM}$ of NO1 for $5 \mathrm{~min}$. A TECAM plate reader was used to intermittently excite the samples at $390 \mathrm{~nm}$ for $5 \mathrm{~min}$, and the emitted fluorescence was recorded at $505 \mathrm{~nm}$. In order to determine possible NO1 unspecific binding, the fluorescence of samples containing the agarose beads and anti-STIM1 antibody + NO1 but lacking of cell lysates was measured, and NO1 fluorescence was normalized accordingly. An additional internal control was performed by immunoprecipitating resting MDA-MB-231 cell lysates with the beads of agarose and using IgG of the same species as the anti-STIM1 antibody (IgG from mouse). The resulting fluorescence after incubating with NO1 was considered as the experimental background, and was subtracted from the fluorescence recorded in the rest of the samples.

\subsection{Cell Migration Measurement}

MDA-MB-231 cells $\left(1 \times 10^{6}\right.$ cells $\left./ \mathrm{mL}\right)$ were shed onto coverslips in 6-well cell culture plates. Cells were grown until $70-80 \%$ confluence was reached. Thereafter, cells were incubated with either the vehicle (control) or the fluorescent $\sigma 2 \mathrm{R} / \mathrm{TMEM} 97$ ligands (NO1, $100 \mathrm{nM}$ for $5 \mathrm{~min}$ or with SM21, $100 \mathrm{nM}$ throughout the experiment). Next, a scratch was performed in the cell culture using a $10 \mu \mathrm{L}$ sterile tip positioned at an angle of $90^{\circ}$ relative to the surface of coverslips. We took pictures of the MDA-MB-231 cell cultures immediately after the scratch and during the following $12 \mathrm{~h}$, leaving at least $6 \mathrm{~h}$, using a light microscope, i.e., the Visicam digital camera and the Visicam 3.0 software (VWR ${ }^{\circledR}$, Madrid, Spain).

\subsection{Cell Proliferation Assay}

The effect of the $\sigma 2 \mathrm{R} / \mathrm{TMEM} 97$ ligands on the proliferation of the breast cancer MDA-MB-231 and MDA-MB-468 cell lines was evaluated using the BrdU cell proliferation assay kit and following the manufacture's protocol. Briefly, MDA-MB-231 cells were shed in a 96-well plate and grown in the presence of the vehicle, PB28, SM21 or the combination of SM21 + PB28. Alternatively, in order to demonstrate the efficiency of the antiproliferative effect of NO1 independently of the genetic background of triple-negative breast cancer cells, we also used the MDA-MB-468 cell line, which was incubated with NO1 under similar experimental conditions to those used in MDA-MB-231 cells. After 24 and $48 \mathrm{~h}$ from the beginning of the experiment, cells were incubated for $2 \mathrm{~h}$ at $37^{\circ} \mathrm{C}$ with a 5-bromo-deoxyuridine (BrdU) solution that was naturally incorporated by the cells. Once the BrdU incubation time was over, the cells were mixed for $30 \mathrm{~min}$ at room temperature with the fixing/denaturing solution provided with the proliferation kit. The incorporated BrdU was analyzed using a specific anti-BrdU antibody and a HRP-secondary antibody. The TMB substrate was added to each well and incubated for $30 \mathrm{~min}$ at room temperature. The reaction was then stopped and the TMB absorbance was immediately recorded at $450 \mathrm{~nm}$ using an TECAN M200 Infinite ELISA plate reader (Tecan Trading AG, Switzerland). 


\subsection{Analysis of the Cell Death Apoptosis Activation by Flow Cytometry (TUNEL) and Caspase Activation Using Fluorogenic Substrates}

The percentage of cell death was evaluated by incubating the MCF10A, MDA-MB-231, and NG115401L cells with propidium iodide (PI; $4 \mu \mathrm{M}$ ) at $37^{\circ} \mathrm{C}$ for $45 \mathrm{~min}$. In the final $30 \mathrm{~min}$, the extracellular medium was supplemented either with the vehicle or NO1 $(100 \mathrm{nM})$. Once the incubation time was over, the fluorescence intensity of PI and NO1 was estimated from images captured at wavelengths of 555/624 and 390/515 nm (Ex/Em, repectively) using a cooled digital CMOS camera (Zyla 4.2, Andor, Belfast, UK) with a 100× objective under an inverted microscope (Nikon Eclipse Ti-2, Amsterdam, The Netherlands) that was controlled by the NIS-Elements AR software (Nikon, Amsterdam, The Netherlands). Additionally, apoptotic cells in the MCF10A and MDA-MB-231 cell cultures subjected to the treatment with either the antineoplastic drug, cisplatin (50 $\mu \mathrm{M}$ for $30 \mathrm{~min}$ ), or the $\sigma 2 \mathrm{R} / \mathrm{TMEM} 97$ ligand, NO1 (100 $\mathrm{nM}$ for $5 \mathrm{~min}$ ), were estimated using the 5-bromo-2'-desoxyurindine (BrdU)-based (TUNEL) commercial kit from Abcam ${ }^{\circledR}$ (Cambridge, UK). Briefly, both cell types were grown until the appropriate percentage of confluence (80\%) was reached. Then, they were treated with the different reagents in order to stimulate cell death. Cells were then trypsinized and concentrated at $5 \times 10^{6}$ cells $/ \mathrm{mL}$, and were furthermore fixed in ice-cold paraformaldehyde (4\%) for $15 \mathrm{~min}$. After having removed the paraformaldehyde solution with PBS, cells were embedded in ice-cold ethanol solution (70\%) for $30 \mathrm{~min}$. Ethanol was removed by centrifugation, and cell aliquots $\left(1 \times 10^{6}\right.$ cells $\left./ \mathrm{mL}\right)$ were stained for $60 \mathrm{~min}$ at $37^{\circ} \mathrm{C}$ with a DNA labeling solution (containing: TdT reaction buffer, TdT enzyme and BrdUTP). The amount of BrdUTP artificially incorporated into the cells was developed using an anti-BrdU-red antibody (diluted 1:20 in the rinse buffer) for $30 \mathrm{~min}$ at room temperature, and subsequently, a 7-AAD/RNase A solution was added to the reaction which was incubated for additional $30 \mathrm{~min}$ at room temperature in the dark. Cells were finally analyzed using a FACS-SCAN flow cytometer (Becton Dickinson, Madrid, Spain). Forward and side scattering were considered in selecting the mask of both cell lines. The fluorescence emitted from the cells within the masks was acquired while we stimulated the samples at a wavelength of $488 / 576 \mathrm{~nm}$ (Ex/Em). Data were presented as a dot plot, considering the SSC-height vs FL2 (BrdU fluorescence). The percentage of apoptotic cells was estimated by comparing the medians obtained from the different cell populations upon analyzing the dot-plot graphs using the Flowing free-software, available from the Cell Imaging Core, Turku Centre for Biotechnology, at the University of Turku and Åbo Akademi University (http://flowingsoftware.btk.fi). Histograms represent the percentage \pm standard error of the mean (S.E.M.) of positive BrdU stained cells as a result of the different treatments.

Finally, analyses of caspases 9, 3, and 8 activation were undertaken by monitoring the fluorescence derived from their respective fluorogenic substrates, and using a Cary eclipse fluorescence spectrophotometer (Agilent@technologies, inc. CA, USA), as previously described [44,76]. Briefly, cells were shed at the appropriate concentrations and incubated in the absence or presence of NO1 (100 $\mathrm{nM}$ for $30 \mathrm{~min}$ at room temperature). Once the incubation time was over, cells were detached and suspended in PBS. Once the cells had been counted and normalized, they were lysated using NP40 buffer for $10 \mathrm{~min}$. Cell lysates were incubated for $2 \mathrm{~h}$ at $37^{\circ} \mathrm{C}$ with $20 \mu \mathrm{M}$ of the respective caspase substrates. Fluorescence of either AMC (7-Amino-4-methylcoumarin) or AFC (7-Amino-4-trifluoromethylcoumarin) emitted as a result of the different caspase activities were acquired using a sprectrofluorophotometer and by exciting the samples at $360 \mathrm{~nm}$ or $400 \mathrm{~nm}$, as well as by recording the emitted fluorescence at $400 \mathrm{~nm}$ or $505 \mathrm{~nm}$, respectively. Histograms represent the mean \pm S.E.M. of the arbitrary unit of fluorescence emitted by each caspase substrate upon NO1 administration, compared to untreated, control cells.

\subsection{Statistical Analysis}

Analysis of statistical significance was performed using a Student's unpaired $t$-test to make a simple comparison between the groups. Additionally, one-way ANOVA combined with the Dunnett's test for multiple comparisons was used. $p<0.05$ was considered to be significant. 


\section{Conclusions}

The structure of $\sigma 2 \mathrm{R} / \mathrm{TMEM} 97$ was recently identified, and although a regulatory role in lipids transport has already been described, here, we show evidence, for the very first time, of a regulatory role of this protein in SOCE. SOCE is crucial for the cancer hallmarks of triple negative MDA-MB-231 breast cancer cells. We observed that NO1 was able to induce a dissociation of the main SOCE components, STIM1 and Orai1, thus impairing $\mathrm{Ca}^{2+}$ entry. NO1 regulates $\sigma 2 \mathrm{R} / \mathrm{TMEM} 97$ activity and its interaction with STIM1. Interaction between NO1 and Orai1 was not observed under our experimental conditions, either before or after SOCE activation with TG. Altogether, our findings can be summarized as follows: (1) MCF10A presented reduced SOCE entry compared to MDA-MB-231. (2) MDA-MB-231 cells express larger amounts of $\sigma 2 R / T M E M 97$, as demonstrated by NO1 fluorescent bioaccumulation and by WB. (3) NO1 incubation reduced SOCE, which is similar to the effect observed by silencing $\sigma 2 \mathrm{R} / \mathrm{TMEM} 97$. (4) NO1 impairs the proliferation and migration of MDA-MB-231 cells, and in parallel, evokes enhanced PI cell loading, as well as enhanced apoptosis through caspase 9 activation (as demonstrated by TUNEL, WB, and by using fluorogenic caspase substrates). (5) NG115-401L cells presented a low amount of STIM1 but a normal level of $\sigma 2 \mathrm{R} / \mathrm{TMEM} 97$ expression, resulting in low NO1 bioaccumulation and low PI cell staining. (6) The overexpression of STIM1 in NG115-401L resulted in an enhanced SOCE, which was also associated with larger NO1 bioaccumulation and PI positive cell staining. This demonstrates once more that SOCE regulation might be the cause of cell death evoked by the novel $\sigma 2 \mathrm{R} / \mathrm{TMEM} 97$ fluorescent ligand, NO1.

In summary, despite the fact that additional experiments involving animal tests are required, according to the presented data, NO1 might become an efficient antineoplastic drug. In fact, experiments with NO1 shed light on novel proteins whose activities are regulated by interactions with $\sigma 2 \mathrm{R}$. Other proteins may be regulated in the same way on the bases of the cell types and physiological functions, suggesting a chaperoning function for $\sigma 2 \mathrm{R} / \mathrm{TMEM} 97$ receptors, and paving the way for more studies in this direction.

Supplementary Materials: The following are available online at http://www.mdpi.com/2072-6694/12/2/257/s1, Figure S1: NO1 colocalization with STIM1 and $\sigma 2 R / T M E M 97$, Figure S2: $\sigma 2 R / T M E M 97$ does not colocalize with mitochondria, Figure S3: NO1 evokes the activation of different caspases in MDA-MB-231 cells, Figure S4: Caspase 9 inhibitor prevents NO1-evoked cells death, Figure S5: NO1 and SM21 alter $\mathrm{Ca}^{2+}$ homeostasis in MDA-MB-231 cells, Figure S6: Effect of SM21 in the PMCA activity, Video S1: NO1 uptake and effects in the MDA-MB-231 cells, Video S2: NO1 uptake and effects in the MCF10A, Video S3: NO1 uptake and effects in the NG115-401L cells.

Author Contributions: C.C. and P.J.C. have performed the experiments. C.A. and F.B. have developed NO1, and further, both have contributed with the discussion of the data and reviewed the manuscript. G.M.S. has reviewed the manuscript and contributed to data discussion. J.A.R. and P.C.R. have been in charge of conceptual design as well as data preparation and discussion, and finally, P.C.R. wrote the manuscript. All authors have read and agreed to the published version of the manuscript.

Funding: This work has been supported by MINECO (BFU2013-45564C2-1-P and BFU2016-74932-C2-1-P) and Junta de Extremadura-FEDER (GR18061 and IB16046). C Cantonero has been granted with a Predoctoral fellowship of the Junta de Extremadura (PD16072).

Conflicts of Interest: Authors declare not conflict of interest.

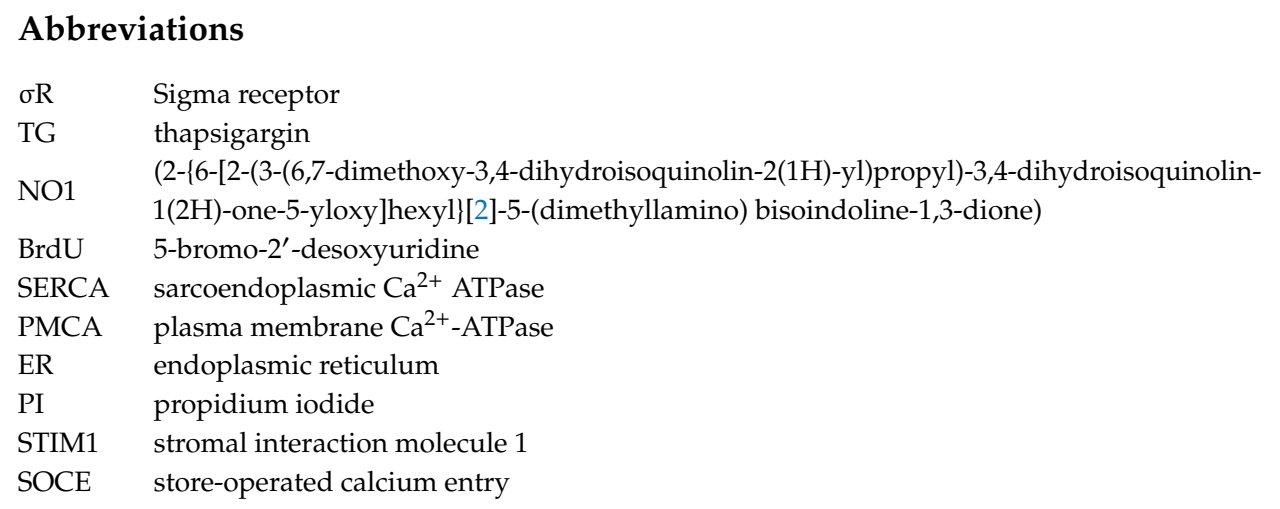




\section{References}

1. Sun, X.; Wei, Q.; Cheng, J.; Bian, Y.; Tian, C.; Hu, Y.; Li, H. Enhanced Stim1 expression is associated with acquired chemo-resistance of cisplatin in osteosarcoma cells. Hum. Cell 2017, 30, 216-225. [CrossRef] [PubMed]

2. Gui, L.; Wang, Z.; Han, J.; Ma, H.; Li, Z. High Expression of Orai1 Enhances Cell Proliferation and is Associated with Poor Prognosis in Human Colorectal Cancer. Clin. Lab. 2016, 62, 1689-1698. [CrossRef] [PubMed]

3. Perez-Riesgo, E.; Gutierrez, L.G.; Ubierna, D.; Acedo, A.; Moyer, M.P.; Nunez, L.; Villalobos, C. Transcriptomic Analysis of Calcium Remodeling in Colorectal Cancer. Int. J. Mol. Sci. 2017, 18, 922. [CrossRef] [PubMed]

4. Motiani, R.K.; Abdullaev, I.F.; Trebak, M. A novel native store-operated calcium channel encoded by Orai3: Selective requirement of Orai3 versus Orai1 in estrogen receptor-positive versus estrogen receptor-negative breast cancer cells. J. Biol. Chem. 2010, 285, 19173-19183. [CrossRef]

5. Jardin, I.; Diez-Bello, R.; Lopez, J.J.; Redondo, P.C.; Salido, G.M.; Smani, T.; Rosado, J.A. TRPC6 Channels Are Required for Proliferation, Migration and Invasion of Breast Cancer Cell Lines by Modulation of Orai1 and Orai3 Surface Exposure. Cancers 2018, 10, 331. [CrossRef]

6. Motiani, R.K.; Zhang, X.; Harmon, K.E.; Keller, R.S.; Matrougui, K.; Bennett, J.A.; Trebak, M. Orai3 is an estrogen receptor alpha-regulated $\mathrm{Ca}^{2+}$ channel that promotes tumorigenesis. FASEB J. 2013, 27, 63-75. [CrossRef]

7. Zhang, S.; Miao, Y.; Zheng, X.; Gong, Y.; Zhang, J.; Zou, F.; Cai, C. STIM1 and STIM2 differently regulate endogenous $\mathrm{Ca}^{2+}$ entry and promote TGF-beta-induced EMT in breast cancer cells. Biochem. Biophys. Res. Commun. 2017, 488, 74-80. [CrossRef]

8. Faouzi, M.; Hague, F.; Potier, M.; Ahidouch, A.; Sevestre, H.; Ouadid-Ahidouch, H. Down-regulation of Orai3 arrests cell-cycle progression and induces apoptosis in breast cancer cells but not in normal breast epithelial cells. J. Cell. Physiol. 2011, 226, 542-551. [CrossRef]

9. Yang, S.; Zhang, J.J.; Huang, X.Y. Orai1 and STIM1 are critical for breast tumor cell migration and metastasis. Cancer Cell 2009, 15, 124-134. [CrossRef]

10. Abate, C.; Niso, M.; Contino, M.; Colabufo, N.A.; Ferorelli, S.; Perrone, R.; Berardi, F. 1-Cyclohexyl-4-(4-arylcyclohexyl) piperazines: Mixed sigma and human $\Delta(8)-\Delta(7)$ sterol isomerase ligands with antiproliferative and P-glycoprotein inhibitory activity. ChemMedChem 2011, 6, 73-80. [CrossRef]

11. Yang, Y.; Jiang, Z.; Wang, B.; Chang, L.; Liu, J.; Zhang, L.; Gu, L. Expression of STIM1 is associated with tumor aggressiveness and poor prognosis in breast cancer. Pathol. Res. Pract. 2017, 213, 1043-1047. [CrossRef] [PubMed]

12. Ferris, R.M.; Tang, F.L.; Chang, K.J.; Russell, A. Evidence that the potential antipsychotic agent rimcazole (BW $234 \mathrm{U}$ ) is a specific, competitive antagonist of sigma sites in brain. Life Sci. 1986, 38, 2329-2337. [CrossRef]

13. Monnet, F.P. [Involvement of sigma receptors in schizophrenic syndromes. Pathophysiological approach. Presse Med. 1993, 22, 218-223. [PubMed]

14. Snyder, S.H.; Largent, B.L. Receptor mechanisms in antipsychotic drug action: Focus on sigma receptors. J. Neuropsychiatry Clin. Neurosci. 1989, 1, 7-15. [CrossRef]

15. Bartz, F.; Kern, L.; Erz, D.; Zhu, M.; Gilbert, D.; Meinhof, T.; Wirkner, U.; Erfle, H.; Muckenthaler, M.; Pepperkok, R.; et al. Identification of cholesterol-regulating genes by targeted RNAi screening. Cell Metab. 2009, 10, 63-75. [CrossRef]

16. Alon, A.; Schmidt, H.R.; Wood, M.D.; Sahn, J.J.; Martin, S.F.; Kruse, A.C. Identification of the gene that codes for the sigma2 receptor. Proc. Natl. Acad. Sci. USA 2017, 114, 7160-7165. [CrossRef]

17. Sengupta, S.; Lingnurkar, R.; Carey, T.S.; Pomaville, M.; Kar, P.; Feig, M.; Wilson, C.A.; Knott, J.G.; Arnosti, D.N.; Henry, R.W. The Evolutionarily Conserved C-terminal Domains in the Mammalian Retinoblastoma Tumor Suppressor Family Serve as Dual Regulators of Protein Stability and Transcriptional Potency. J. Biol. Chem. 2015, 290, 14462-14475. [CrossRef]

18. Pati, M.L.; Hornick, J.R.; Niso, M.; Berardi, F.; Spitzer, D.; Abate, C.; Hawkins, W. Sigma-2 receptor agonist derivatives of 1-Cyclohexyl-4-[3-(5-methoxy-1,2,3,4-tetrahydronaphthalen-1-yl)propyl]piperazine (PB28) induce cell death via mitochondrial superoxide production and caspase activation in pancreatic cancer. BMC Cancer 2017, 17, 51. [CrossRef] 
19. Spruce, B.A.; Campbell, L.A.; McTavish, N.; Cooper, M.A.; Appleyard, M.V.; O’Neill, M.; Howie, J.; Samson, J.; Watt, S.; Murray, K.; et al. Small molecule antagonists of the sigma-1 receptor cause selective release of the death program in tumor and self-reliant cells and inhibit tumor growth in vitro and in vivo. Cancer Res. 2004, 64, 4875-4886. [CrossRef]

20. van Waarde, A.; Rybczynska, A.A.; Ramakrishnan, N.K.; Ishiwata, K.; Elsinga, P.H.; Dierckx, R.A. Potential applications for sigma receptor ligands in cancer diagnosis and therapy. Biochim. Biophys. Acta 2015, 1848, 2703-2714. [CrossRef]

21. McDonald, E.S.; Mankoff, J.; Makvandi, M.; Chu, W.; Chu, Y.; Mach, R.H.; Zeng, C. Sigma-2 ligands and PARP inhibitors synergistically trigger cell death in breast cancer cells. Biochem. Biophys. Res. Commun. 2017, 486, 788-795. [CrossRef] [PubMed]

22. Zeng, C.; McDonald, E.S.; Mach, R.H. Molecular Probes for Imaging the Sigma-2 Receptor: In Vitro and In Vivo Imaging Studies. Handb. Exp. Pharmacol. 2017, 244, 309-330. [CrossRef] [PubMed]

23. Vilner, B.J.; Bowen, W.D. Modulation of cellular calcium by sigma-2 receptors: Release from intracellular stores in human SK-N-SH neuroblastoma cells. J. Pharmacol. Exp. Ther. 2000, 292, 900-911. [PubMed]

24. Cassano, G.; Gasparre, G.; Niso, M.; Contino, M.; Scalera, V.; Colabufo, N.A. F281, synthetic agonist of the sigma-2 receptor, induces $\mathrm{Ca}^{2+}$ efflux from the endoplasmic reticulum and mitochondria in SK-N-SH cells. Cell Calcium 2009, 45, 340-345. [CrossRef] [PubMed]

25. Zhang, H.; Cuevas, J. Sigma receptors inhibit high-voltage-activated calcium channels in rat sympathetic and parasympathetic neurons. J. Neurophysiol. 2002, 87, 2867-2879. [CrossRef]

26. Zeng, C.; Vangveravong, S.; Xu, J.; Chang, K.C.; Hotchkiss, R.S.; Wheeler, K.T.; Shen, D.; Zhuang, Z.P.; Kung, H.F.; Mach, R.H. Subcellular localization of sigma-2 receptors in breast cancer cells using two-photon and confocal microscopy. Cancer Res. 2007, 67, 6708-6716. [CrossRef]

27. Chu, U.B.; Mavlyutov, T.A.; Chu, M.L.; Yang, H.; Schulman, A.; Mesangeau, C.; McCurdy, C.R.; Guo, L.W.; Ruoho, A.E. The Sigma-2 Receptor and Progesterone Receptor Membrane Component 1 are Different Binding Sites Derived from Independent Genes. EBioMedicine 2015, 2, 1806-1813. [CrossRef]

28. Bali, N.; Arimoto, J.M.; Morgan, T.E.; Finch, C.E. Progesterone antagonism of neurite outgrowth depends on microglial activation via Pgrmc1/S2R. Endocrinology 2013, 154, 2468-2480. [CrossRef]

29. Crudden, G.; Chitti, R.E.; Craven, R.J. Hpr6 (heme-1 domain protein) regulates the susceptibility of cancer cells to chemotherapeutic drugs. J. Pharmacol. Exp. Ther. 2006, 316, 448-455. [CrossRef]

30. Niso, M.; Riganti, C.; Pati, M.L.; Ghigo, D.; Berardi, F.; Abate, C. Novel and Selective Fluorescent sigma2-Receptor Ligand with a 3,4-Dihydroisoquinolin-1-one Scaffold: A Tool to Study sigma2 Receptors in Living Cells. Chembiochem 2015, 16, 1078-1083. [CrossRef]

31. Wang, Y.; Xu, J.; Xia, X.; Yang, M.; Vangveravong, S.; Chen, J.; Mach, R.H.; Xia, Y. SV119-gold nanocage conjugates: A new platform for targeting cancer cells via sigma-2 receptors. Nanoscale 2012, 4, 421-424. [CrossRef] [PubMed]

32. Gasparre, G.; Abate, C.; Carlucci, R.; Berardi, F.; Cassano, G. The sigma1 receptor agonist (+)-pentazocine increases store-operated $\mathrm{Ca}^{2+}$ entry in MCF7sigma1 and SK-N-SH cell lines. Pharmacol. Rep. 2017, 69, 542-545. [CrossRef] [PubMed]

33. Abate, C.; Niso, M.; Lacivita, E.; Mosier, P.D.; Toscano, A.; Perrone, R. Analogues of sigma receptor ligand 1-cyclohexyl-4-[3-(5-methoxy-1,2,3,4-tetrahydronaphthalen-1-yl)propyl]piperazine (PB28) with added polar functionality and reduced lipophilicity for potential use as positron emission tomography radiotracers. J. Med. Chem. 2011, 54, 1022-1032. [CrossRef] [PubMed]

34. Kopp, F.; Wagner, E.; Roidl, A. The proto-oncogene KRAS is targeted by miR-200c. Oncotarget 2014, 5, 185-195. [CrossRef] [PubMed]

35. Longhitano, L.; Castracani, C.C.; Tibullo, D.; Avola, R.; Viola, M.; Russo, G.; Prezzavento, O.; Marrazzo, A.; Amata, E.; Reibaldi, M.; et al. Sigma-1 and Sigma-2 receptor ligands induce apoptosis and autophagy but have opposite effect on cell proliferation in uveal melanoma. Oncotarget 2017, 8, 91099-91111. [CrossRef] [PubMed]

36. Olivieri, M.; Amata, E.; Vinciguerra, S.; Fiorito, J.; Giurdanella, G.; Drago, F.; Caporarello, N.; Prezzavento, O.; Arena, E.; Salerno, L.; et al. Antiangiogenic Effect of (+/-)-Haloperidol Metabolite II Valproate Ester [(+/-)-MRJF22] in Human Microvascular Retinal Endothelial Cells. J. Med. Chem. 2016, 59, 9960-9966. [CrossRef] 
37. Georgiadis, M.O.; Karoutzou, O.; Foscolos, A.S.; Papanastasiou, I. Sigma Receptor (sigmaR) Ligands with Antiproliferative and Anticancer Activity. Molecules 2017, 22. [CrossRef]

38. Niso, M.; Abate, C.; Contino, M.; Ferorelli, S.; Azzariti, A.; Perrone, R.; Colabufo, N.A.; Berardi, F. Sigma-2 receptor agonists as possible antitumor agents in resistant tumors: Hints for collateral sensitivity. ChemMedChem 2013, 8, 2026-2035. [CrossRef]

39. Gonzalez, D.; Espino, J.; Bejarano, I.; Lopez, J.J.; Rodriguez, A.B.; Pariente, J.A. Caspase-3 and -9 are activated in human myeloid HL-60 cells by calcium signal. Mol. Cell. Biochem. 2010, 333, 151-157. [CrossRef]

40. Zbidi, H.; Redondo, P.C.; Lopez, J.J.; Bartegi, A.; Salido, G.M.; Rosado, J.A. Homocysteine induces caspase activation by endoplasmic reticulum stress in platelets from type 2 diabetics and healthy donors. Thromb. Haemost. 2010, 103, 1022-1032. [CrossRef]

41. Cai, Y.; Zheng, Y.; Gu, J.; Wang, S.; Wang, N.; Yang, B.; Zhang, F.; Wang, D.; Fu, W.; Wang, Z. Betulinic acid chemosensitizes breast cancer by triggering ER stress-mediated apoptosis by directly targeting GRP78. Cell Death Dis. 2018, 9, 636. [CrossRef] [PubMed]

42. Wu, J.; Yang, C.; Guo, C.; Li, X.; Yang, N.; Zhao, L.; Hang, H.; Liu, S.; Chu, P.; Sun, Z.; et al. SZC015, a synthetic oleanolic acid derivative, induces both apoptosis and autophagy in MCF-7 breast cancer cells. Chem. Biol. Interact. 2016, 244, 94-104. [CrossRef] [PubMed]

43. Rosado, J.A.; Lopez, J.J.; Gomez-Arteta, E.; Redondo, P.C.; Salido, G.M.; Pariente, J.A. Early caspase-3 activation independent of apoptosis is required for cellular function. J. Cell. Physiol. 2006, 209, 142-152. [CrossRef]

44. Lopez, J.J.; Redondo, P.C.; Salido, G.M.; Pariente, J.A.; Rosado, J.A. N,N,N', $\mathrm{N}^{\prime}$-tetrakis(2-pyridylmethyl) ethylenediamine induces apoptosis through the activation of caspases- 3 and -8 in human platelets. A role for endoplasmic reticulum stress. J. Thromb. Haemost. 2009, 7, 992-999. [CrossRef] [PubMed]

45. McAndrew, D.; Grice, D.M.; Peters, A.A.; Davis, F.M.; Stewart, T.; Rice, M.; Smart, C.E.; Brown, M.A.; Kenny, P.A.; Roberts-Thomson, S.J.; et al. ORAI1-mediated calcium influx in lactation and in breast cancer. Mol. Cancer Ther. 2011, 10, 448-460. [CrossRef] [PubMed]

46. Kar, P.; Parekh, A.B. Distinct spatial $\mathrm{Ca}^{2+}$ signatures selectively activate different NFAT transcription factor isoforms. Mol. Cell 2015, 58, 232-243. [CrossRef]

47. Albarran, L.; Lopez, J.J.; Jardin, I.; Sanchez-Collado, J.; Berna-Erro, A.; Smani, T.; Camello, P.J.; Salido, G.M.; Rosado, J.A. EFHB is a Novel Cytosolic $\mathrm{Ca}^{2+}$ Sensor That Modulates STIM1-SARAF Interaction. Cell. Physiol. Biochem. 2018, 51, 1164-1178. [CrossRef]

48. Juska, A.; Redondo, P.C.; Rosado, J.A.; Salido, G.M. Dynamics of calcium fluxes in human platelets assessed in calcium-free medium. Biochem. Biophys. Res. Commun. 2005, 334, 779-786. [CrossRef]

49. Redondo, P.C.; Rosado, J.A.; Pariente, J.A.; Salido, G.M. Collaborative effect of SERCA and PMCA in cytosolic calcium homeostasis in human platelets. J. Physiol. Biochem. 2005, 61, 507-516. [CrossRef]

50. Azzariti, A.; Colabufo, N.A.; Berardi, F.; Porcelli, L.; Niso, M.; Simone, G.M.; Perrone, R.; Paradiso, A. Cyclohexylpiperazine derivative PB28, a sigma2 agonist and sigma1 antagonist receptor, inhibits cell growth, modulates P-glycoprotein, and synergizes with anthracyclines in breast cancer. Mol. Cancer Ther. 2006, 5, 1807-1816. [CrossRef]

51. Aydar, E.; Onganer, P.; Perrett, R.; Djamgoz, M.B.; Palmer, C.P. The expression and functional characterization of sigma (sigma) 1 receptors in breast cancer cell lines. Cancer Lett. 2006, 242, 245-257. [CrossRef] [PubMed]

52. Srivats, S.; Balasuriya, D.; Pasche, M.; Vistal, G.; Edwardson, J.M.; Taylor, C.W.; Murrell-Lagnado, R.D. Sigma1 receptors inhibit store-operated $\mathrm{Ca}^{2+}$ entry by attenuating coupling of STIM1 to Orai1. J. Cell Biol. 2016, 213, 65-79. [CrossRef] [PubMed]

53. Redondo, P.C.; Rosado, J.A. Store-operated calcium entry: Unveiling the calcium handling signalplex. Int. Rev. Cell Mol. Biol. 2015, 316, 183-226. [CrossRef] [PubMed]

54. Stathopulos, P.B.; Ikura, M. Store operated calcium entry: From concept to structural mechanisms. Cell Calcium 2017, 63, 3-7. [CrossRef] [PubMed]

55. Putney, J.W., Jr. New molecular players in capacitative Ca ${ }^{2+}$ entry. J. Cell Sci. 2007, 120, 1959-1965. [CrossRef] [PubMed]

56. Riad, A.; Zeng, C.; Weng, C.C.; Winters, H.; Xu, K.; Makvandi, M.; Metz, T.; Carlin, S.; Mach, R.H. Sigma-2 Receptor/TMEM97 and PGRMC-1 Increase the Rate of Internalization of LDL by LDL Receptor through the Formation of a Ternary Complex. Sci. Rep. 2018, 8, 16845. [CrossRef] 
57. Ebrahimi-Fakhari, D.; Wahlster, L.; Bartz, F.; Werenbeck-Ueding, J.; Praggastis, M.; Zhang, J.; Joggerst-Thomalla, B.; Theiss, S.; Grimm, D.; Ory, D.S.; et al. Reduction of TMEM97 increases NPC1 protein levels and restores cholesterol trafficking in Niemann-pick type C1 disease cells. Hum. Mol. Genet. 2016, 25, 3588-3599. [CrossRef]

58. Zhang, C.; Thomas, D.W. Stromal Interaction Molecule 1 rescues store-operated calcium entry and protects NG115-401L cells against cell death induced by endoplasmic reticulum and mitochondrial oxidative stress. Neurochem. Int. 2016, 97, 137-145. [CrossRef]

59. Albarran, L.; Lopez, J.J.; Amor, N.B.; Martin-Cano, F.E.; Berna-Erro, A.; Smani, T.; Salido, G.M.; Rosado, J.A. Dynamic interaction of SARAF with STIM1 and Orai1 to modulate store-operated calcium entry. Sci. Rep. 2016, 6, 24452. [CrossRef]

60. Lopez, E.; Frischauf, I.; Jardin, I.; Derler, I.; Muik, M.; Cantonero, C.; Salido, G.M.; Smani, T.; Rosado, J.A.; Redondo, P.C. STIM1 phosphorylation at $\mathrm{Y}^{316}$ modulates its interaction with SARAF and the activation of SOCE and ICRAC. J. Cell Sci. 2019, 132. [CrossRef]

61. Garg, G.; Kumar, D.; Asim, M.; Husain, S.A.; Das, B.C.; Kar, P. Multiplex Reverse Transcriptase-PCR for Simultaneous Detection of Hepatitis, B., C., and E Virus. J. Clin. Exp. Hepatol. 2016, 6, 33-39. [CrossRef] [PubMed]

62. Wheeler, K.T.; Wang, L.M.; Wallen, C.A.; Childers, S.R.; Cline, J.M.; Keng, P.C.; Mach, R.H. Sigma-2 receptors as a biomarker of proliferation in solid tumours. Br. J. Cancer 2000, 82, 1223-1232. [CrossRef] [PubMed]

63. Makvandi, M.; Tilahun, E.D.; Lieberman, B.P.; Anderson, R.C.; Zeng, C.; Xu, K.; Hou, C.; McDonald, E.S.; Pryma, D.A.; Mach, R.H. The sigma-2 receptor as a therapeutic target for drug delivery in triple negative breast cancer. Biochem. Biophys. Res. Commun. 2015, 467, 1070-1075. [CrossRef] [PubMed]

64. Mori, T.; Hayashi, T.; Hayashi, E.; Su, T.P. Sigma-1 receptor chaperone at the ER-mitochondrion interface mediates the mitochondrion-ER-nucleus signaling for cellular survival. PLoS ONE 2013, 8, e76941. [CrossRef]

65. Ghelardini, C.; Galeotti, N.; Bartolini, A. Pharmacological identification of SM-21, the novel sigma(2) antagonist. Pharmacol. Biochem. Behav. 2000, 67, 659-662. [CrossRef]

66. Wu, Y.; Bai, X.; Li, X.; Zhu, C.; Wu, Z.P. Overexpression of sigma-1 receptor in MCF-7 cells enhances proliferation via the classic protein kinase C subtype signaling pathway. Oncol. Lett. 2018, 16, 6763-6769. [CrossRef]

67. Krajewski, S.; Krajewska, M.; Ellerby, L.M.; Welsh, K.; Xie, Z.; Deveraux, Q.L.; Salvesen, G.S.; Bredesen, D.E.; Rosenthal, R.E.; Fiskum, G.; et al. Release of caspase-9 from mitochondria during neuronal apoptosis and cerebral ischemia. Proc. Natl. Acad. Sci. USA 1999, 96, 5752-5757. [CrossRef]

68. Lopez, J.J.; Salido, G.M.; Gomez-Arteta, E.; Rosado, J.A.; Pariente, J.A. Thrombin induces apoptotic events through the generation of reactive oxygen species in human platelets. J. Thromb. Haemost. 2007, 5, 1283-1291. [CrossRef]

69. Hernandez-Morales, M.; Sobradillo, D.; Valero, R.A.; Munoz, E.; Ubierna, D.; Moyer, M.P.; Nunez, L.; Villalobos, C. Mitochondria sustain store-operated currents in colon cancer cells but not in normal colonic cells: Reversal by non-steroidal anti-inflammatory drugs. Oncotarget 2017, 8, 55332. [CrossRef]

70. Jardin, I.; Albarran, L.; Salido, G.M.; Lopez, J.J.; Sage, S.O.; Rosado, J.A. Fine-tuning of store-operated calcium entry by fast and slow $\mathrm{Ca}^{2+}$-dependent inactivation: Involvement of SARAF. Biochim. Biophys. Acta Mol. Cell Res. 2018, 1865, 463-469. [CrossRef]

71. Gilabert, J.A.; Parekh, A.B. Respiring mitochondria determine the pattern of activation and inactivation of the store-operated $\mathrm{Ca}^{2+}$ current I(CRAC). EMBO J. 2000, 19, 6401-6407. [CrossRef] [PubMed]

72. Li, X.; Chen, W.; Zhang, L.; Liu, W.B.; Fei, Z. Inhibition of store-operated calcium entry attenuates $\mathrm{MPP}(+)$-induced oxidative stress via preservation of mitochondrial function in PC12 cells: Involvement of Homer1a. PLoS ONE 2013, 8, e83638. [CrossRef] [PubMed]

73. Rao, W.; Zhang, L.; Su, N.; Wang, K.; Hui, H.; Wang, L.; Chen, T.; Luo, P.; Yang, Y.F.; Liu, Z.B.; et al. Blockade of SOCE protects HT22 cells from hydrogen peroxide-induced apoptosis. Biochem. Biophys. Res. Commun. 2013, 441, 351-356. [CrossRef] [PubMed]

74. Shanmughapriya, S.; Rajan, S.; Hoffman, N.E.; Zhang, X.; Guo, S.; Kolesar, J.E.; Hines, K.J.; Ragheb, J.; Jog, N.R.; Caricchio, R.; et al. $\mathrm{Ca}^{2+}$ signals regulate mitochondrial metabolism by stimulating CREB-mediated expression of the mitochondrial $\mathrm{Ca}^{2+}$ uniporter gene MCU. Sci. Signal. 2015, 8, ra23. [CrossRef] [PubMed] 
75. Cui, X.; Zhang, Y.; Wang, Z.; Yu, J.; Kong, Z.; Ruzic, L. HIIT changes the expression of MuRF1 and MAFBx proteins and proteins involved in the MTOR pathway and autophagy in rat skeletal muscle. Exp. Physiol. 2019, 104, 1505-1517. [CrossRef] [PubMed]

76. Bejarano, I.; Espino, J.; Gonzalez-Flores, D.; Casado, J.G.; Redondo, P.C.; Rosado, J.A.; Barriga, C.; Pariente, J.A.; Rodriguez, A.B. Role of Calcium Signals on Hydrogen Peroxide-Induced Apoptosis in Human Myeloid HL-60 Cells. Int. J. Biomed. Sci. 2009, 5, 246-256. [PubMed]

C 2020 by the authors. Licensee MDPI, Basel, Switzerland. This article is an open access article distributed under the terms and conditions of the Creative Commons Attribution (CC BY) license (http://creativecommons.org/licenses/by/4.0/). 